تاريخ الإرسال (28-020-201)، تاريذ قبول الشرر (14-03-2020)

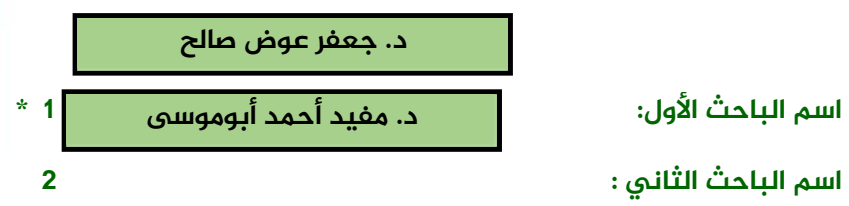

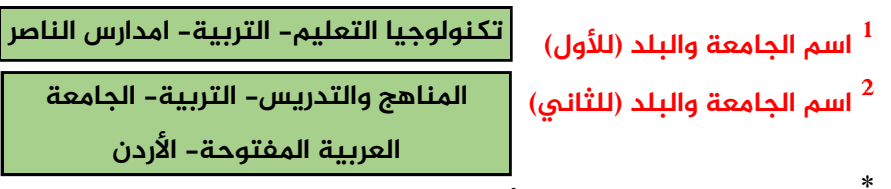
"البريد الالكتروندي للباحث المرسل:

E-mail address:

\section{M abumosa@aou.edu.jo}

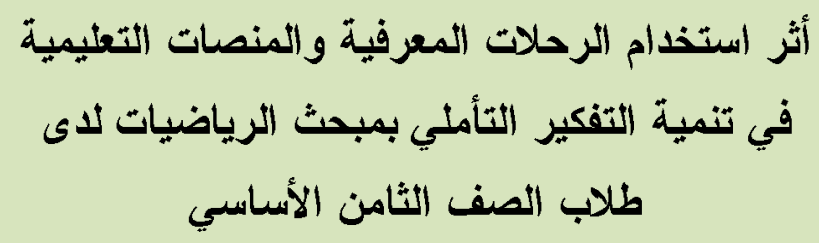

أثر استخدام الرحلات المعرفية والمنصات التطليمية

طلاب الصف الثامن الأساسي لئي التربي

\title{
https://doi.org/10.33976/IUGJEPS.29.2/2021/38
}

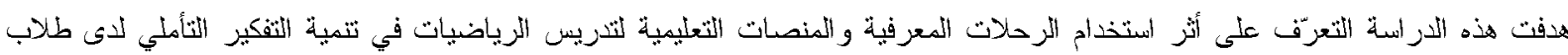
الصف الثامن الأساسي. و اعتمدت اللدراسة المنهج شبه التجريبي على عينة تكوّن أفرادها من (90) طالباً من طلاب الصف الصف الثامن الأساسي في مدرسة

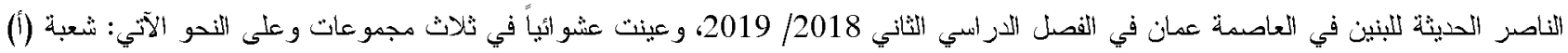

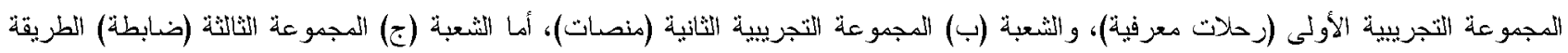
الاعتيادية. ولتحقيق اغر اض الدر استة جرى إعداد اختبار لمهار ات للتفكير التأملي توفرت لها مؤشرات الصدق و التثات. و أظظهرت النتائج وجود فروق ذات دلالة إحصائية عند (م=0.05) بين متوسطات علامات مجموعات اللدراسة الثلاث في اختبار مهارات التفكير التأملي، إذ وجد أنَّ هناكت فرقاً دالاً إحصائيا بين متوسطات علامات طلاب المجموعة التجريبية الأولى والثانية (رحلات معرفية، منصات) ومتوسطات علامات طلاب المجموعة الضابطة

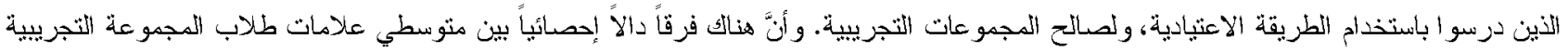
الثانية الذين درسوا باستخدام المنصات التعليمية و طلاب المجموعة التجريبية الأولى الذين درسوا باستخدام الترحلات المعرفية، ولصالح المجموعة الثجريبية الثانية.

$$
\text { كلمات مفتامية: الرحلات الدعزفية، الدنصات النعليسية ، مهارات النفكير الثأللي. الرياضيات، الصف الثامن الأساسي }
$$

\section{The Effect of Using Web-Quests and Learning Platforms for Teaching Mathematics to Develop the Reflective Thinking among Eighth Grade Students.}

\section{Abstract:}

The study aimed to identify the effect of using web-quests and learning platforms in teaching Mathematics to develop reflective thinking among eighth Grade students. The study adopted the semi-experimental approach. The study sample consisted of (90) eighth graders at Al-Nasser Modern School -a private school in Amman- in the second semester 2018-2019. The study sample was randomly distributed into three groups -each consisting of 30 students- as follows: The first group represented the first experimental group in which students studied using web-quests, the second group represented the second experimental group in which students studied using learning platforms, and the last group represented the control group in which studied using the traditional method.

To achieve the objectives of the study, a test for reflective thinking was developed; results showed statistical differences at $(\mathrm{a}=0.05)$ among the average scores of the three study groups. A statistical difference between the average scores of experimental groups and the average score of the control group was found favoring the experimental groups. In addition, a statistical difference between the average scores of the second experimental group and the average scores of the first experimental group was found favoring the second experimental group.

Keywords: Web-Quests, Learning Platforms, Reflective thinking skills, Math, eighth grade. 


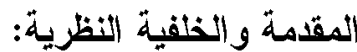

المعرفة الإنسانية معرفة منكاملة ومنر ابطة، و الرياضيات من المعارف الإنسانية الأساسية، فهي علم يتكامل ويتر ابط مع مجالات المعرفة الأخرى؛ باعتبارها عاملاً مهماً وفاعلاً في تحفيز الفكر المعرفي، و التنهوض بمحتوى الإدر الك العقلي لدى الطلبة، فهي تساعدهم على استيعاب فروع المعرفة الأخرى، من خلال عرض وتفسير وتحليل البيانات. فتعليم الرياضيات لم يُعد يقتصر على مبدأ تعليم حل المسائل وتعلم مهار ات حسابية فحس: بل تعدى إلى كيفية التعامل مع الظاهر الإنسانية، ومع المحتوى، و التو أصل مع الآخرين، وإجر اء المناقثنات، و إيجاد الحلول للمشكلات، واكمال المهامات التعليمية التعلمية، وتجاوز إثكالية بيان المعارف؛ وكل ذلك ينعكس على مستوى التحصيل الأكاديمي للطلبة في شتى فروع المعرفة، وعلى تحقيق النجاح في مجالات الحياة العملية. ويُعدّ التفكير التأملي أحد أنماط التفكير، التي صنَّها العلماء بأنَّها من العمليات العقلية العليا التي يلجأ إليها الفرد عندما مواجهة موقف أو مشكلة، تتطلب إيجاد الحلول المناسبة، ومن هنا نظهر أهمية التقكير التأملي في إكساب الطالب مهارة التأني و التبصر ، وزيادة الخبرة في التعمق في الأمور، والخروج من إطلر المعرفة الملموسة إلىى المجردة، فعند ممارسة الطالب مهار ات التفكير التأملي، برتقي في تفكيره، وصولاً إلىى قدة التجريد المفاهيمي، مما يعزز تقته بنفسه. وكذلك تعمل على تحفيز و إثارة بُنيته المعرفية لتحقيق فهم أعمق للمحتوى، وتمكينه من نقل الخبرات الحالية وتطبيقها في مو اقف جديدة، مع الاستفادة

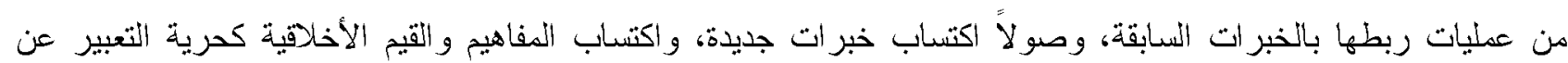

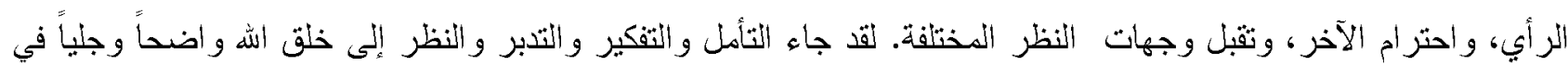

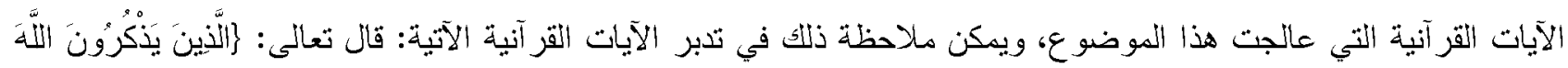

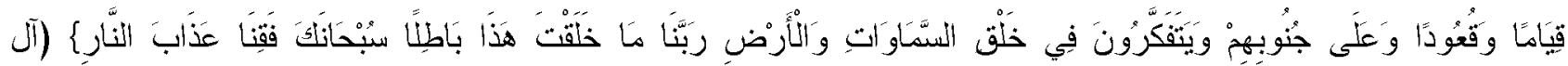

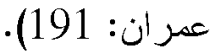

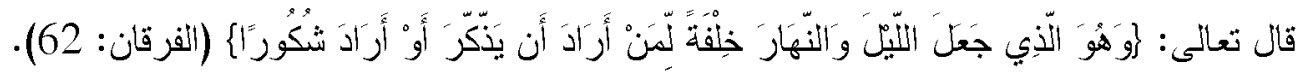
وقد طرح جون ديوي (John Dewey) المذكور في العارضدة (2009) في كتابه "كيف نفكر؟" (How we think) مفهوم التفكير التأملي بافتر اض أنَّ التعلّم ينثأ عن عملية التأمل (التفكير العميق)، وتولدت من هذا النوع من التفكير أنواع أخرى، وهي: التفكير الناقد Thinking Critical)، وحلّ المشكلة (Problem Solving)، والتفكير ذو المستوى العالي .((Higher Level Thought أنَّ الفرد في التفكير التأملي يتأمل الموقف، ويحلاك إلىى عناصره، ويرسم الخطط النلازمة لفهمه حتى يصل إلىى النتائج التي يتطلبها هذا الموقف، ثم تقويم هذه النتاثج في ضوء الخطط التي وضعت له، ويبدأ التفكير التأملي عندما يشعر الإنسان بالإرتباكَ إز اء مشكلة يو اجهها أو مسألة يود حلّها، فيعمل على تحديد المشكلة، وفرض فروض الحل، ومحاولة اختبارها. إنَّ ممارسة المعلم لمهارات التفكير التأملي تُؤدي إلىى التتوع في أسداليب التعليم والثقويم، وتحسين طر ائق التدريس، وبذلك يستطيع المعلم ممارسة مسؤولياته بحرفية عالية. فقد يكون التأمل في صورة حوار داخلي ذاتي، وقد يكون جماعياً، يتم فيه تبادل الآراء والأفكار والخبرات التي هن شأنها الارتقاء بالأداء المهني، حيث يُعدّ التفكير التأملي أحد أُدوات التتمية المستدامة للمعلمين؛ لأنَّه يُكسبهم مستوى عاليًا من نفاذ البصيرة، وعت النظر حول أدائهم وسلوكهم، بحيث بعمل على تطويره 
وتغييره وتحسينه، وذلك باستخدام أدوات التفكير التنأملي المتعدة كالمذكرات اليومية، و السجلات القصصية، وقو ائم المر اجعة، وصحف التأمل، وتدوين الملاحظات بشكل منهجي ومنظم، وكذلك المشاركة في الحوارات التأملية مع الآخرين، ومع الذات (الأستاذ، 2011). (1) (1)

ويرى لوينز (Lyons, 2010) أنَّ مر احل التفكير التأملي تتمثل بالوعي بالمشكلة، وفهم تلك المشكلة، ووضع الحلول المقترحة، وتصنيف البيانات، واكتشاف العلاقات، ومن ثم استتباط نتائج الحلول المقترحة، وقبول أو رفض الحلول، واختبار

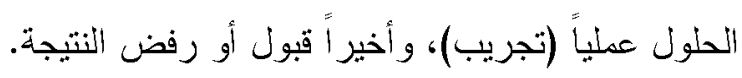
ويتضح مما تقدم أنَّ مر احل التقكير التثأملي تتثابه وخطو ات حلّ المشكلة المتشتلة بتأمل وتبصر الموقف من خلال تحديد المثكنة، ماهيتها وطبيعتها ووصفها، ومعرفة أسباب حدوث المثكنة، وكيفية حدوثها، وفرض الثروض، واختبار حدوثها، ووضع الحلول المقترحة، واختبار أفضلها. واشار عفافة و اللولو (2002 ) الىى خمس مهار ات للتفكير التأملي، وهي:

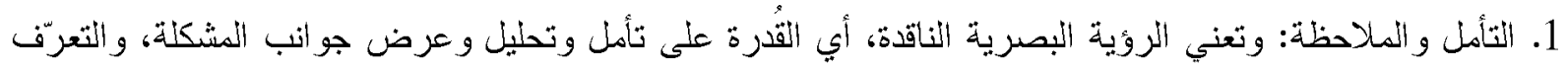
على محتو اها بيياناتها ومكوناتها، إذ بيكن اكتثاف العلاقة الموجودة بصرياً. 2. الكثف عن المغالطات: وفيد يجري توضيح الفجوات في المشكلة بتحديد، وتوضيح العلاقات غير الصحيحة أو الطبيعية و المنطقية، و الخطأ في إنجاز المهمات التربوية. 3. الوصول اللى استتاجات: وهي القُدرة على إيضاح العلاقة المنطقية المحددة من خلال تحليل مضمون المشكلة وطبيعتها، و التوصل إلى فرض الفروض، و التوصل لحلول مناسبة. 4. إعطاء تفسير ات مقنعة: وهي المقدرة على وضع الخطط، و المقترحات الؤ اقعية المبنية على المعلومات و المعرفة الصحيحة لحلّ المشكلة القائمة من خلال التصور ات الدماغية للمشكلة الموجودة. 5. وضع حلول مقترحة: وهي وضع حلول بخطوات منطقية لحل المشكلة المطروحة، وتقوم هذه الخطوة على تصور ات ذهنية منوقعة لحلّ المشكلة المطروحة. وقد اعتد الباحثان تصنيف عفانة واللولو (2002) في تحديد مهارات التفكير التأملي الخمس؛ باعتبار أنهّا تثنل العمليات العقلية الواجب تضمنها في التفكير التأملي، وروعي فيها التكامل و التدرج. إن المتابع للأدب التربوي المتخصص في تدريس الرياضيات يجد العديد من الاستر اتيجيات وطر ائق التدريس المعاصرة القائمة على استخدام وسائل التكنولوجيا الحديثة لتنمية المفاهيم ومهارات التفكير ، وبالتالي بمكن تتمية مهار ات التفكير التأملي

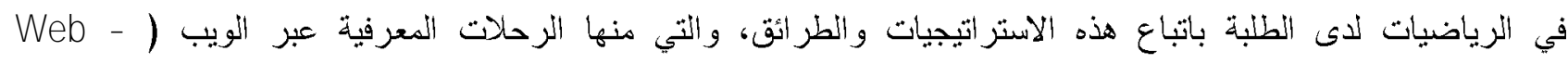
(Quests)، و المنصدات التعليمية (Learing Platforms)،والتي سنتاول ذكرهما لاحقا وغيرها من استر اتيجيات التكنولوجيا الحديثة، التي تعل على دمج وتوظيف الوسائط المتعددة في العملية التعليمية التعليمة. اولا: الرحلاث المعرفية) (Web Quests) إنَّ أول من تتبه إلى استر اتيجية الرحلة المعرفية عبر الويب هم مجموعة من الباحثين في قسم تكنولوجيا التعليم في جامعة سان دييجو بولاية كاليفورنيا في الولايات المتحدة الأمريكية، وكان على رأسهم بيرن دوج (Beriane Dodgo)، 
ومارش توم (March tom). ويرى فيلز و الين (Allen, 2002 fiedler) أنَّ الزرحلات المعرفية عبر الويب عبارة عن . . نشاط تعليمي بعتمد على الإنترنت، ويُعالج في حلّ مشكلات حقيقة لدى الطلبة، وذلك باستخدامهر مهار ات التفكير، بالاعتماد على الوسائل الإكترونية المتاحة، ويُؤدي المعلم فيها دور المرشد و المخطط و المنظم لعملية التعلّم المستمدة من الإنترنت. وتظهر أهمية الرحلات المعرفية في تمكينها الطلبة من دقة البحث، وتحفيز مهار ات التفكير العليا، وتتمية وتحصيل المعرفة

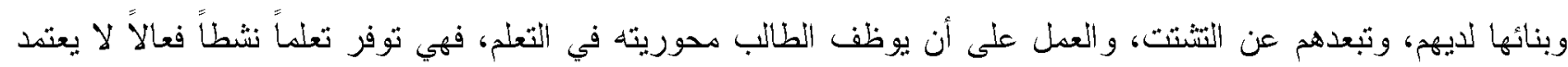
متل المسار التقليدي على حفظ المعلومات واسترجاعها. فهي تُسهّل على الطالب استخلاص المهارات وتوظيفها، وتفتح المجال Skylar, Higgins, and ) أمامه لإيجاد الحول للأسئلة والمشكلات الو اقعية من خلال المصدادر الإكترونية عبر الإنترنت

.(Boone, 2007

و اتفق جودة (2008)؛ وحسنين (Hassanien,2006 )، على أنَّ هناك ستة عناصر أساسية لبناء الرحلات المعرفية،

1) المقدمة: وتتضسن عرض الدرس، ومهام الطالب، و التمهيد له بطرق متعددة، مثل: عبار ات محفزة، أو صور مثيرة شاملة لموضوع الدرس، أو تقديم مجموعة من الأسئلة حول أفكار الدرس الرئيسة بهدف تثجيع الطالب على اكتئف المطلوب، وعرض ملخص الرحلة على شكل تقدير ، وعرضد أمام الزملاء أو الإجابة عن أسئلة المعلم. 2) المهام: وهي ما يجب على الطالب إنجازه في نهاية النشاط، وبالنتيجة فإنَّ إتمام المهام يمكن الطلبة من تعلّم المادة إنة الدر اسية، ويرى دودج (Dodge 2002)) أنَّ هناك أنو اعاً متعددة من المهام يؤديها الطلبة، وهي: 3) العمليات أو الإجراءات: فيها يجري تقسيم هذه العمليات على الطلبة الموزعين على مجموعتين -إن كان العمل جماعياً - ويؤدي التوزيع هنا إلى أن بدرك كل طالب مدى تقدمه في إنجاز هذه المههة.

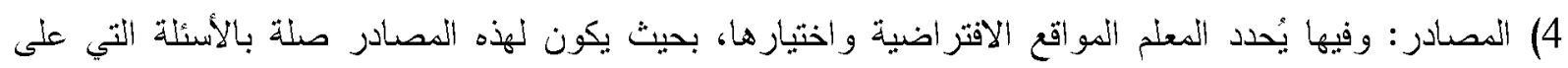
الطالب إيجاد حول لها؛ مما بسيهل عمل الطالب. 5) التثويم: وفيها يعمل الطلبة على تقويم أنفسهم، وذللك بقو ائم رصد، أو مجموعة على الارجات، وبالنتيجة تمكين الطالب من مقارنة ما تعلمه و أنجزه. 6) الخاتمة: وفيها يجزي تحفيز الطلبة على التواصل في الحصول على المعرفة، والاستفادة مما توصلوا، وذلك بالتعزيز المـادي أو التعزيز المعنوي، ويتم فيها أيضاً تقديم ملخص لما جرى البحث حوله .

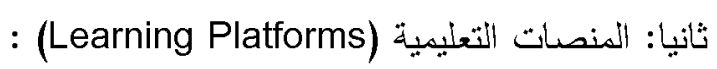
تُعدّ تكنولوجيا التعليم واحدة من القوى المؤثرة في العملية التعليمية، فقد أصبح التحدي الأهم للمعلم هو كيفية إيصال المعلومات بشكل متسدٍ إلىى الطلبة جميعه، وذلك باستخدام أنظمة التعليم الإكتروني والحاسوب، وتأتي منصات التعليم الإكترونبة في مقدمة تقنيات الجيل الثاني من الويب، والتي تشهد إقبالاً متز ايداً على توظيفها من أعضداء الهيئة التدريسية و المعلمين في المدارس. و المنصـات التعليمية هي: "مجموعة من التطبيقات التي توفر طرقاً تعليمية مختلفة عبر الإنترنت في سياق تعليهي متتوع، بحيث تكون الدر اسدة عبر تلك المنصدات التعليمية متز امنة أو غير متز امنة" (الجهني، 2016: 19). 
و المنصات التحليمية بيئة تعليمية تفاعلية تجمع بين مديزات أنظمة إدارة المحتوى الإكتروني، وشبكات التواصل الاجتماعي، وتُكِّن الطالب من نشر الدروس و الأهداف، ووضع الو اجبات، وتطبيق الأنثطة التعليمبة، وتُكّن المعلم من إجراء الاختبار ات الإكترونية، وتوزيع الأدوار بين الطلبة للأنشطة والواجبات، وتُساعد أيضاً على تبادل الأفكار والآراء بين المعلم و الطالب، كما تُبح لأولياء أمور الطلبة فرص التواصل مع المعلمين، والاطلاع على نتائج أبنائهر؛ مما يُساعد على تحقيق مخرجات تعليمية ذات جودة عالية (العنيزي، 2017 ). وقد أظهرت نتائج دراسة كل من بيرتل وجيم وكارلوس (Bertil, Jaime and Carlos, 2015)؛ ودر اسدة جيانج (Zhongyun, 2011) تعليمية، كما أنَّها ثُقدّم نموذجاً تعليمياً مدمجاً يجمع بين التعلّم الصفي و التعلم عبر الإنترنت، وذلك لتحسين فرص التعلّم، وتحفيز الطلبة، ورفع مستوى التعليم باتباع منهج مُنظّم، و استخدام فعّال للمنصة التعليمية من المعلمين و الطلبة.

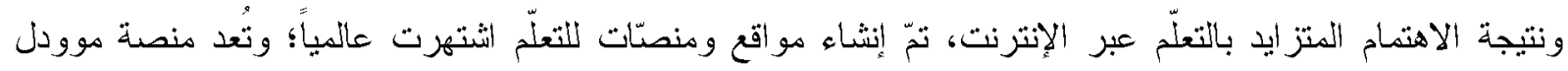
(MOODLE) المفتوح، لذا اكتسبت شهرة واسعة حول العالم، إذ استخدمت من عدد كبير من المؤسسات التعليمية والأكاديمية في أنحاء العالم المختلفة، وذلك بتبادل المعلومات بين المستخدمين المنتشرين جغر افياً، حيث تتو افر فيها مميزات تسدح بإنثاء عمليات تقييم للطلبة بالاختبار ات والاستطلاعات عبر الإنترنت، إلى جانب تقديم مجموعة واسعة من الأدوات التكميلية لدعم عمليتي التعليم و التعلّمّ؛ لأنها تمتاز بتكلفة أقلى، وأمن أكبر، ومرونة أكثر (Costa, Alvelos, and Teixeira, 2012) وتتمتع منصدة الموودل بميزات متعددة، جعلتها أكثر شيوعاً واستخداماً في العملية التعليمية و الأكاديمية، كما ذكرها دحلان (2012)، وهي: - مجانبة ومفتوحة المصدر، ويمكن لأبي شخص أو مؤسسة تعليمية الحصول على الدور ات التشرييية و المز ايبا التعليمية الكبيرة لها بمجرد التسجيل في الموقع.وكذلك بناء معرفة الطالب بتجاربه ومؤهلاته، و مُتاحة بعدد كبير من اللغات العالمية ومتاحة باللغة العربية أيضاً ولكن بشكل جزئي، ونتيح للجامعات و المدارس إجراء الامتحانات للطلبة وإعطائهم العلامات الكترونياً، وبشكل سريع ومباشر وو توفير مزايا أخرى في التعلّم الإكتروني، اطلع الباحثان على العديد من الدر اسات السدابقة وفيما يلي استعر اض لبعض تلأك الدر اسات. ساعد النمو المتسارع في الأعو ام الأخبرة على تطور تقنيات الأجزة المتنقلة، المتمثل في زيادة قُرة بنية الثبكات، وأصبحت القناعة بأهمية التكنولوجيا في العملية التعليمية تزداد يوماً بعد يوم، حتى أصبح من مسلمات هذا العصر ضرورة الاستفادة بما يُعرَف بالتقنيات الحديثة ذات الصلة بالعمل التعليمي لتحقيق أهداف التعلّ على أفضل وجه وبأفضل المستويات الممكنة (إطميزي، 2010).

قام لي ويانج (Li and Yang, 2007) بإجر اء دراسة لمعرفة فاعلية استخدام الرحلات المعرفية عبر الويب في تتمية مهار ات التفكيز العلمي وزيادة الدافعية للتعلّم وزيادة التحصيل في مادة اللغة الانجليزية لطلاب المرحلة الابتدائية، في اليابان، وتكونت العينة من (108) طالباً، واستخدم الباحثان المنهج شبه التجريبي ولتحقيق أهداف الدراسة استخدم الباحثان اختبارًا 
لمهار ات التفكير العلمي، واختبارًا تحصيلياً، ومقياساً لدافعية التعلًّ، وأظهرت النتائج وجود فروق ذات دلالة إحصائية في أدو ات الدر اسة جمبعها ولصدالح المجموعة التجريبية. وأجرى الفار (2011) دراسة هدفت إلى تعرّف مدى فاعلية استخدام الرحلات المعرفى عبر الوىب في تدريس الجغر افيا في مستوى التفكىر التأملي والتحصدىل لدى طلاب الصف الثامن الأساسي في محافظة شمال فطاع غزة، وتكونت عىنة الدر استة من (61) طالباً، واستخدم الباحثان المنهج شبه التجريبي، وكانت أداتا الدر اسة مقياسًا للتفكير التأملي، واختباراً تحصيليًا، وأظهرت النتائج فاعلية الرحلات المعرفية بدلانة إحصائية في تحسين مهارات التفكير التأملي والتحصبل في الجغر افيا لدى الطلبة. وهدفت در اسة أوديتور وروليدا (Wuditor and Roleda, 2014) إنى معرفة أثثر (Web Quest) على التفكير الناقد للطلاب و اكتساب المحتوى المعرفي وأداء المهام والتصورات في الفيزياء الأساسية، وأجريت الدراسة في الفلبين، وقد استخدمت المنهج شبد التجريبي ذب المجموعة التجرييية الواحدة، حيث تكونت من (20) طلباً وطالبة في المرحلة الثانوية ، طُبِّق عليهم مقياس للتفكير الناقد و اختبار تحصيلي، وأظهرت النتائج الدر استة أنَّ المشاركين حققو انمواً كبيراً في كل من التفكير الناقد و اكتساب المعرفة، وأنَّه استجابو أشكل إيجابي لاستخدام نموذج (Web Quest) وكان هناك أثر إيجابي على التعاون و الإبداع و التحفيز وتعزيز المعرفة، لكن لبس على إدارة الوقت، وإلى وجود علاقة ما بين منخفضة ومعتدلة بين التفكير الناقد و أداء المهام، وأنَّ الطلبة ينظرون إلى (Web Quest) بشكل إيجابي بغض النظر عن قدر اتهم. بينما هدفت در اسة عبدالمجيد (2014) الكثف عن أثر استخدام استر اتيجية الويب كويست (Web Quests) في تدريس حساب المثلثات على تتمية مهار ات التفكير التأملي و التعلّم السريع لدى طلاب الصف الأول الثانوي، وتكونت عينة الدراسة من (84) طالباً، قسدت إلىى مجموعتين تجرييية وضابطة، طُبِّق عليها مقياس أداء نواتج التعلّم، واختبار مهارات

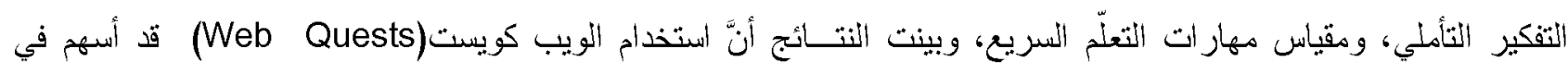
تحسين مهار ات: الرؤية البصرية، والكثف عن المغالطات، ووضع حلول مقترحة، ولم تُساهم في تحسين مستوى مهارات: الوصول إلىى أستنتاجات، وإعطاء تفسيرات مقنعة، ولم تُساهم في تحسين مهار ات حلّ المشكلات الرياضية. وقامت الثيخ (2016) بدراسة هدفت التعرّت على أثز الرحلات المعرفية عبر الويب في تتمية مهارات التفكير التأملي و الاتجاه نحو الإنترنت، وقد استخدت المنهج شبه التجريبي، وتكونت العينة من (66) طالبة من طالبات جامعة الامير سطام

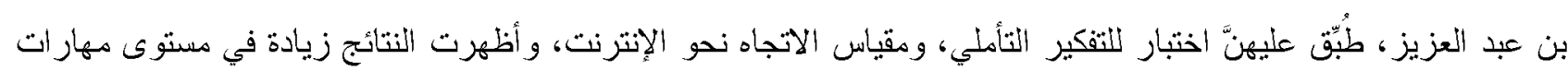
التقكير التأملي، وأثراً ملحوظاً وايجابياً على الاتجاه نحو الإنترنت، ولصالح المجموعة التجريبية. وأجرى جالجن وكوك (Calgin and koc2017، ) دراسة هدفت إلى تقصي أثزر توظيف الويب كويست كأداة مساعدة لتتمية التقكير الناقد لدى طلبة الصف السادس في مادة الرياضيات في تركيا، وتكونت عينتها من (36) طالب وطالبة، و استخدم الباحثان مقياس للتفكير الناقد كأداة لقياس مهارات التفكير الناقد سواء في التطبيق القبلي او البعدي، وقد أظهرت النتائج أنَّ افر اد المجموعة التجريبية تطورا في مهار ات التحليل، و التغيير و التتظيم الذاتي. أما أبو جبلة (2017) فقد أجرى دراسة هدفت التعرّت على أثر الرحلات المعرفية في تتمية التفكير البصري في مقرر الرياضيات لدى طالبات المرحلة المتوسطة في مدينة الرياض، وتكونت العينة من (40) طالبة، مستخدماً المنهج شبة التجريبي، 
وقد استخدم اختباراً للتفكير البصري، وأثارت النتائج إلى وجود فروق دالله إحصائيًاً في اختبار التنفكير البصري، ونصالح المجمو عة التجر يبية.

و أجرى مصطفى (2017) دراسة هدفت ثياس فاعلية استراتيجية الويب كويست في تتمية التفكير الناقد في الرياضيات و الاتجاه نحو التعلّم القائم على الإنترنت لدى طلبة معهد القاهرة العاني للعلوم الإدارية، وتكونت عينة الدر استة من (40) طالباً وطالبة، طُبّْق عليها مقياس للاتجاه نحو التعلّم القائم على الإنترنت، واختبار مهار ات التقكير الناقد، وأظهرت النتائج فاعلية

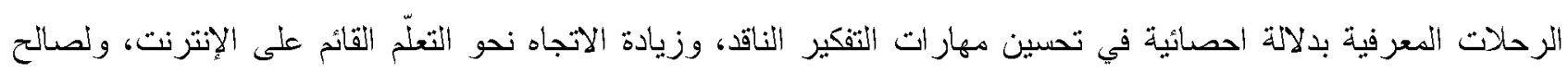
المجمو عة التجرييية.

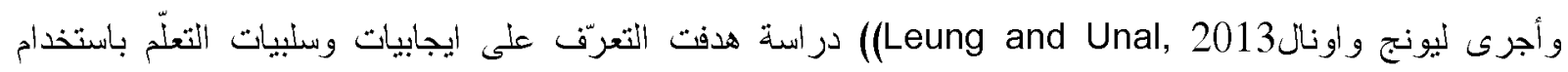
الويب كويست و الربط بين تعلّم القر اهة والكتابة و التكنولوجي في فلوردا بالو لايات المتحدة الأمريكية، واستخدم الباحثان المنهج الوصفي المسحي، وتكونت العينة من (596) معلم ومعلمة، طُبِق عليهم بطاتة ملاحظة ومقابلة و استبانة، وكثفت النتائج أنَّ

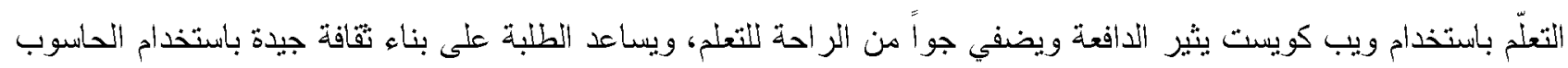
و التكنولوجيا، ويطور مهار ات التقكير الناقد، ويُساعد على تفريد التعلّم. أجرى السعدي (2011) دراسة هدفت التعزّت على فاعلية استخدام نظام المودل في تتمية مهارات التفكير الرياضي و التحصيل، وقد تألفت العينة من (20) طالباً وطالبة من طلبة الصف السابع بمنطقة شمال الباطنة، واستخدم الباحثان المنهج

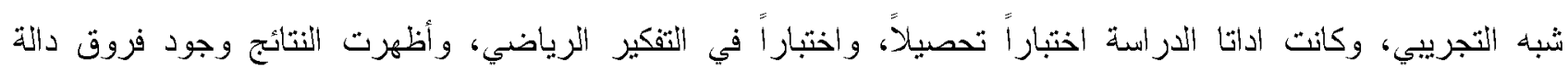
إحصائياً بين متوسطي المجمو عتين الضابطة و التجريبية وفي الاختبارين، ولصانح المجمو عة التجريبية. وأجرت الحدرب (2018) در استها للكثف عن فاعلية توظيف المنصات التعليمية في التفكير العلمي والمهارات الحياتية لدى طلبة كلية العلوم التربوية في الجامعات الأردنية، على عينة من (47) طالباً وطالبة من طلبة كلية العلوم التربوية في الجامعة الأردنية، مستخدمة المنهج شبه التجريبي، ولتحقيق اهداف الدراسة استخدمت الباحثة أداتين هما اختبار لقياس مهار ات التفكير العلمي، وآخر لقباس المهارات الحياتية. وبينت النتائج وجود فروق دالة إحصائياً في اختباري التفكير العلمي ومقياس المهار ات الحياتية، ولصدالح المجمو عة التجريبية. وقام صالح (2014) بدر استه التي هدفت إلى الكثف عن فاعلية استراتيجية الرحلات المعرفية عبر الويب في تدريس مادة الكيمياء في تتمية التفكير التأملي و التحصبل الدراسي لدى طلاب الصف الأول الثانوي، وقد تم اختبار عينة قصدية بلغت (66) طالبة من مدرستي المساعيد الثانوية للبنات و العريش الثانوية للبنات، إحداها تمثل المجموعة التجرييية، والأخرى تمثل المجموعة الضابطة، ولتحقيق أهداف الدر اسة نّ إعداد اختبار تحصيلي في الكمياء، واستبانة التفكير التأملي، وقد أثنارت نتائج الدراسة إلى وجود فروق دالة إحصائياً بين متوسطي درجات الطالبات على الاختبار التحصيلي واستبانة التفكير التأملي للمجمو عتين التجريبية والضابطة، ولصدالح المجموعة التجرييية. كما هدفت دراسة خليفة (2016) إلى التعرّت على أثثر توظيف الرحلات المعرفية عبر التويب في تدريس الاقتصاد

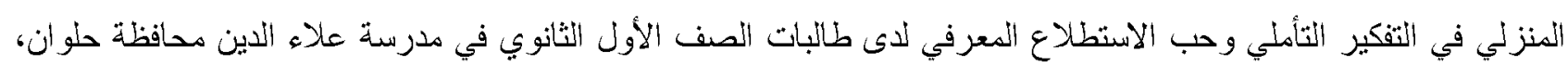
وقد ثألفت عينة الدراسة من (82) طالبة، طُبِق عليهنَّ مقياس للتفكير التأملي، وآخر لقياس حب الاستطلاع المعرفي، وقد 
كثفت النتائج حدوث تحسن في مستوى التفكير التأملي وحب الاستطلاع المعرفي لدى طالبات المجموعة التجريبية مقارنة بالمجمو عة الضابطة.

وأجرى الجمل (2016) دراسة هدفت التعرّف على فاعلية الرحلات المعرفية عبر الويب في الاستيعاب المفاهيمي وتتمية مهار ات التفكير التأملي من خلا مادة الققه لدى طلاب المرحلة الثانوية الأزهرية، وقد تكونت عينة الدر اسدة من (61) طالباً من معهز أبو الغر الثانوي في كفر الزيات في مصر، ولتحقيق هدف الدراسة تمّ استخدام اختبارت مهارات التفكير التأملي، واختبار الاستيعاب المفاهيمي، وقد أثنارت النتائج إلى فاعلية الرحلات المعرفية عبر الويب في تتمية الاستبعاب المفاهيمي لموضوعات الفقه لدى الطلبة وكذلاك تنمية مهار ات التفكير التأملي لديهر. من خلال استعر اض الدر اسات السدابقة تبين أنَّها ناقثت مختلف المفاهيم ذات الصلة الوثيقة بالرحلات المعرفية والمنصات التعليمية في التفكير التأملي، إضدافة إلى أنَّا قد تمت في مجتمعات مختلفة ذات حجم وطبيعة مختلفة، وضمن متغيرات متعددة تتاولتها، و عينات و أساليب جمع البيانات وتحليلها المتبعة في الرحلات المعرفية والمنصات التعليمية في التفكير التأملي.

ويتضح من استعر اض الدر اسات السابقة عدم وجود دراسات تتاونت أثز استخدام الرحلات المعرفية و المنصات التعليمية في تتمبة التفكير التأملي في مبحث الرياضيات لدى طلبة الصف الثامن الأساسي في الأردن من حيث منهج الدراسة: اتفقت الدراسة الحالية مع جميع الدراسات السابقة في استخدام المنهج شبه التجريبي. بينما استخدمت باستثاء دراسة ليونج واونال (Leung and Unal, 2013) ومن حيث أداة الدر اسة: تتوعت الأدوات المستخدمة في الدر اسات السابقة تبعاً للمتغيرات التابعة التي تقبسها؛ فبعضها استخدم الاختبار ات، وبعضها مقياساً للاتجاهات، وبعضها استخدم مقاييس لأنواع التفكير المتعددة. وتثابهت الدر استة الحالية دع كثبر من الدراسات التي استخدمت اختبار مهار ات التفكير التأملي. وقد تميزت الدر اسة الحالية عن الدراسات السدابقة باستخدامها اختبار التفكير التأملي كمتغير تابع لأثر استخدام الرحلات المعرفية و المنصات التعليمية لدى طلبة الصف الثامن الأساسي في الأردن من حيث مجتمع الدر استة وعينتها: اتفقت الدراسة الحالية مع جميع الدراسات السابقة في اختيار مرحلة التعليم المدرسي لتطبيق در استها عليها، باستثاء در اسة ليونج واونال (Leung and Unal, 2013)، و الحدرب (2018)، حيث كانت عينتها من طلبة المرحلة الجامعية، وقد أجريت الدراسات السابقة في بيئات مختلفة محلية وعربية و عالمية. من حيث الهدف: اتفقت الدراسة الحالية مع جميع الاراسات السابقة من حيث الكثف عن فاعلية الرحلات المعرفية أو المنصات التعليمية في تتمية العديد من المهاز ات التعليمية كالتحصيل و التفكير والاتجاهات ... وتميزت عنها بأنها هدفت قياس أثز استخدام الرحلات المعرفية والمنصات التعليمية معاً في تتمية التفكير التأملي لدى طلاب الصف الثنامن في الأردن. وتتميز الدر اسدة الحالية عن الدراسات السابقة بتتاولها لموضوع أثر استخدام استر اتيجيتي الرحلات المعرفية والمنصات التعليمية في التفكير التأملي لدى طلبة الصف الثامن في مادة الرياضيات، وهو ما لم تتناوله أبي من الدراسات في حدود علم الباحثان، فهي من أو ائل الدر اسات التي تتاولت هذا الموضوع بمتغير اته المستقلة و التابعة. و واستفادت الدر اسة الحالية من الدراسات السابقة في بناء وتدعيم الإطار النظري للإر استة الحالية مع الاستفادة من مر اجع الدر اسـات السابقة، وتحديد مشكلة الدر اسدة وصياغة أسئلتها، وبناء أدوات الدر اسدة، وإجر اءاتها، ومناقتشة نتائجها. 


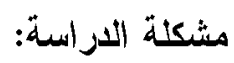

Trends in International Mathematics' and أظهرت ننائج الدراسات الدولية في العلوم والرياضيات فalley) Science Study

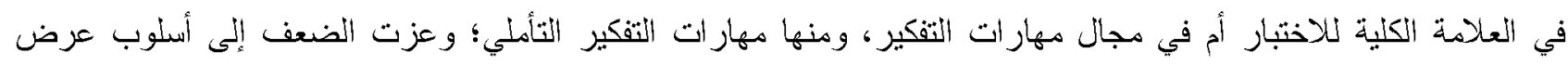

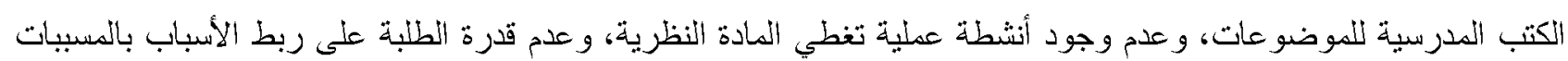

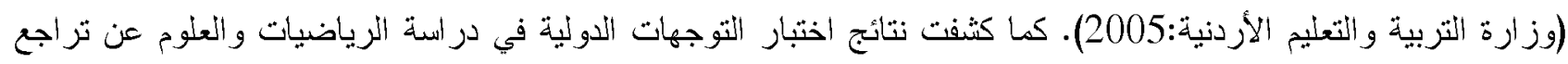

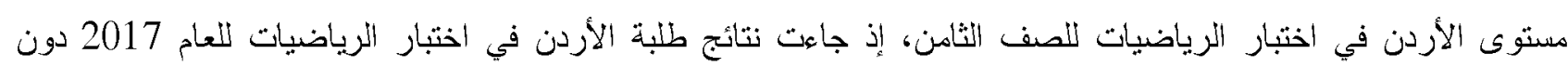
المتوسط (وز ارة التربية و التعليم الأردنية، 2017).

و أثنارت دراسة العتوم (2013) إلى وجود قصور لدى المعلمين والطلبة في مهارات التنكير التأملي. وتلمس الباحث

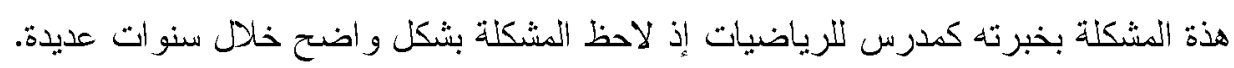

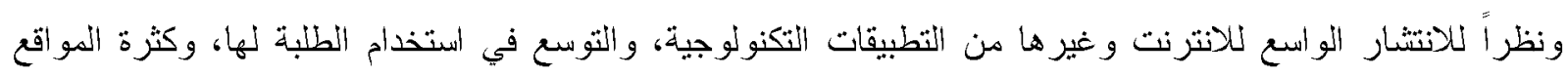

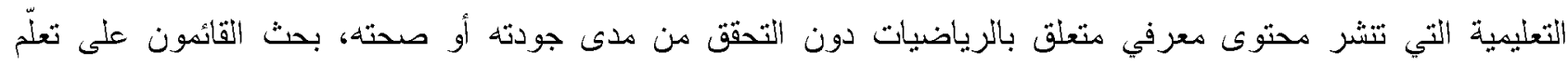

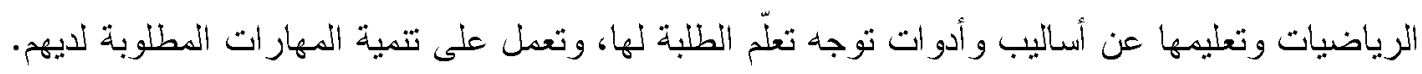

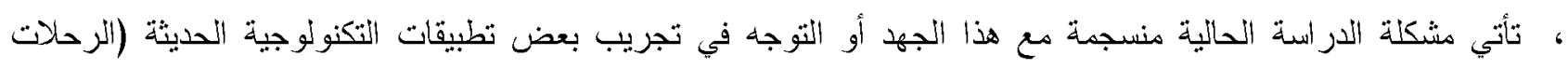

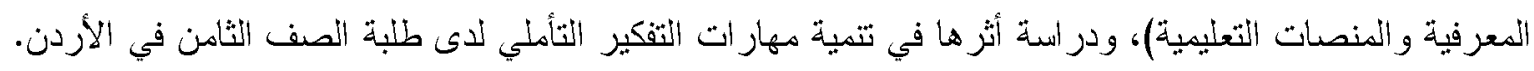

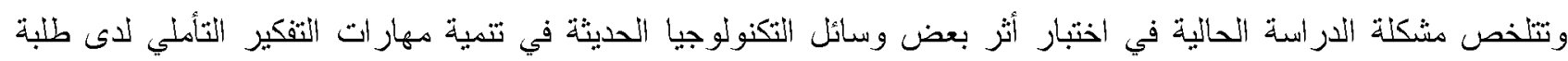

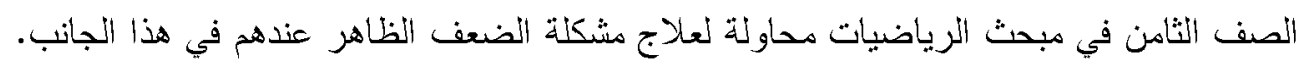

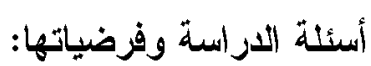

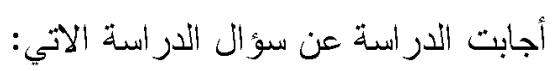

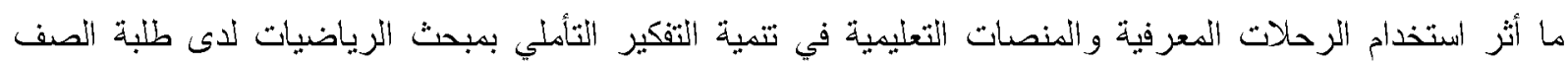
الثنامن الأساسي؟ ويتفر ع عن هذا الأسئلة الفر عية الآتية: هل هناك فروق جوهرية في تتمية مهارة التأمل و الملاحظة في مبحث الرياضيات لطلبة الصف الثامن تعزى لطريقة التدريس

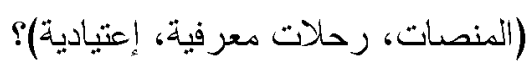

هل هذاك فروق جوهرية في تتمبة مهارة الكثف عن المغالطات في مبحث الرياضيات لطلبة الصف الثامن تعزى لطريقة

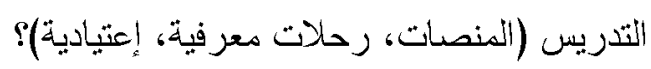

هل هناك فروق جوهرية في تتمية مهارة الوصول إلى استتاجات في مبحث الزياضيات لطلبة الصف الثامن تعزى لطريقة

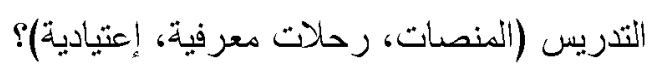


هل هنالك فروق جوهرية في تتمية مهارة اعطاء تفسيرات مقنعة في مبحث الرياضيات لطلبة الصف الثامن تعزى لطريقة التدريس (المنصات، رحلات معرفية، إعتبادية)؟

هل هنالك فروق جوهرية في تتمية مهارة وضع حلول مقترحة في مبحث الرياضيات لطلبة الصف الثامن تعزى لطريقة التدريس (المنصات، رحلات معرفية، إعتبادية)؟

\section{فرضيات الار اسة:}

لا توجد فروق دالة احصائياً عند مستوى الالالة (a=0.05) بين منوسطات درجات طلبة الصف التامن الأساسي في

مجموعات الدر استة في اختبار التفكير التأملي تُعزى لطريقة التدريس (الرحلات المعرفية، المنصات الطريقة الاعتيادية )؟ لا توجد فروق دالة احصدائياً عند مستوى الدلالة (a=0.05) بين متوسطات درجات طلبة الصف الثامن الأساسي في مجوعتي الدراسة في المهارات الفز عية (التقأمل و الملاحظة، الكثف عن المغالطات، الوصول إلى استتاجات، اعطاء تفسيرات

مقنعة، وضع حلول مقترحة) تُعزى لطريقة التدريس (المنصات التعليمية، الرحلات المعرفية، الطريقة الاعتبادية )؟ أهمية الادراسة:

تبرز أهمية الدراسة من خلال نقديمها لمعرفة نظرية حول كيفية عمل الرحلات المعرفية، والمنصات التعليمية، و استخدامها في تدريس الرياضيات وأثر ذللك في تنمية التفكير التأملي لدى طلبة المرحلة الاساسية الخاصة للصف الثنامن الأساسي، كونها -على حد علم الباحثان واطلاعهما- من الدراسات المحلية القلاثل التي ستتاول الرحلات المعرفية و المنصات التعليمية في مجال الزياضيات.

كما تظهر أهميتها في مقارتتتها بين استراتيجيات مختلفة توظيف التكنونوجيا في تدريس الرياضيات؛ فقد ساهت في اكتثاف العديد من الفو ائد التي يمكن أن يستفيد منها القائمين على تدريس الرياضيات. كما ظهرت الأهمية في تقديم الدراسة لأداة لقياس التقكير التأملي جرى تطوير ها و التأكد من تمتعهما بالخصائص السيكومترية بالطرق العلمية، قد بستخدهما باحثون

\section{في دراسات مستقلية. حود الار اسة ومحدداتها: \\ اقتصرت الدر استة على الحدود الآتية:}

الحدود البثرية: اقتصرت الدراسة على طلبة الصف الثامن الأساسي في مدرسة الناصر الحديثة. الحدود المكانية: اقتصرت الدراسة على طلبة مدرسة الناصر الحديثة، التابعة لإدارة التعليم الخاص في محافظة العاصمة - عمان. الحدود الززمانية: الفصل الثثاني من العام الدراسي 2019/2018، من 2019/2/10 إلى 2019/4/15. الحدود الموضو عبة: 
- اقتصر تطبيق الدراسة على تصميم وحدة (المجسمات) من كتاب الزرياضيات للصف الثثن الأساسي المقرر من وز ارة التربية و التعليم في الأردن للعام الدر اسي 2018/2019 بما يتو افق مع الرحلات المعرفية، و المنصدات التعليمية. - مقياس مهار ات التفكير التتألمي الخمس، وهي: (التأمل و الملاحظة، الكثف عن المغالطات، الوصول إلى أستتاجات، إعطاء تفسير ات مقنعة، وضع حلول مقترحة). مصطات الار اسة: تعرّن المصطلحات الو اردة في الدر استة مفاهيمياً وإجر ائياً على النحو الآتي:الرحلات المعرفية: هي "ثشاطات تهدف إلى تحديث الإمكانبات الفكرية المتغايرة من الاستيعاب و التحليل و التوليف،

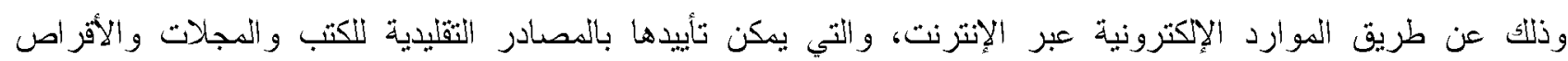
المدمجة و غير ذلاك" (الحربي، 2016: 20).

وتُعرّت الرحلات المعرفية إجر ائيًاً بأنها: أنشطة تربوية هادفة وموجهة استقصدئيًا تستند إلىى عمليات البحث في المواقع

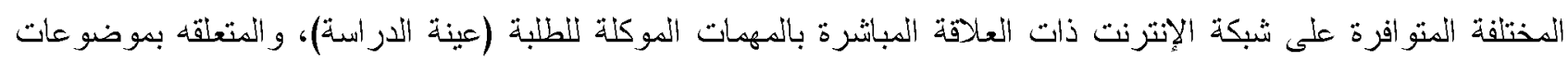
وحدة (المجسمات) من كتاب الرياضيات المقرر لطلبة الصف الثامن الأساسي في الأردن للعام الدراسي 2018/2019 جرى تدريسها وفق الرحلات المعرفية. المنصات التعليمية: "مجموعة متعددة من تطبيقات الجيل الثاني من الويب (Web2.0) التي تقدم أساليباً غبر مشابهة للتعلم عبر الإنترنت، في سياق منعدد حيث تحدث مز امنة التعليم بالمدرسة أو عدم مزامنتها" (الجهني، 2016: 78).

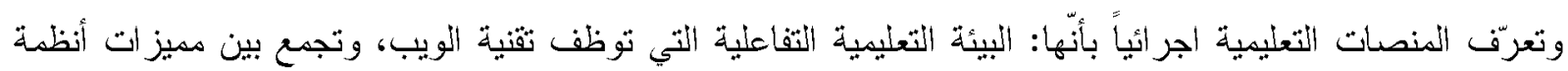
إدارة المحتوى الإكتروني وشبكات التواصل الاجتماعي، وتمكّن المعلم من نشر دروس وحدة (المجسمات) من كتاب الرياضيات المقرر، ونتاجاتها التعليمية والتعلمية، وتصميم الو اجبات وتطبيق الأنثطة التعليمية المتعلقة بمحتوى الوحدة، والاتصال بطلبة الصف الثامن الأساسي في مدرسة الناصر من خلال المنصة التعليمية للمدرسة.

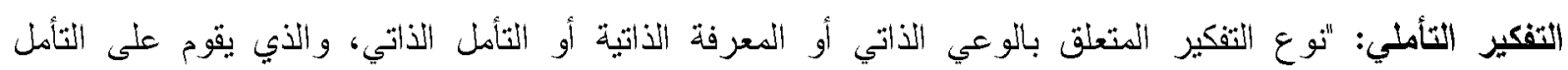
و الملاحظة الذاتبة والعناية العميقة، وتأمل الثخص للموقف الذبي أمامه ويحلا إلى عناصره، ورسم التدابير الضرورية لفهده حتى يبلغ النتائج ثم تقويم النتائج بأخذ التثابير في الاعتبار". ويُعرَّف إجر ائياً بأند نمط من التفكير، يتأمل فيه الطلبة (عينة الدراسة) المو اقف التي عُرضت عليهم في اختبار التفكير التأملي الذبي أعدّه الباحثان، إذ قبس بالدرجة الكلية التي حصل عليها طلاب الصف الثامن الأساسي باجاباتهم على فقرات الاختبار - الإن

سارت اللراسة تبعا للإجزاءات الآتية: منهج الاراسة: اعتمدت الدراسة المنهج شبه التجريبي لمناسبته تحقيق أهدافها؛ للكثف عن أثر استخدام الرحلات المعرفية و المنصات التعليمية في تتمية التفكير التأملي بمبحث الرياضيات لدى طلاب الصف الثامن الأسدسي. 
مجتمع الار اسة وعينتها:

استهدفت الدراسة طلبة الصف الثامن في منطقة ماركا التعليمية والذي ييلغ عددهم حوالي 6780 طالبا وطالبة، واختبرت عينة الدراسة لتكون (90) طالباً من طلاب الصف الثامن الأساسي في مدرسة الناصر الحديثة للبنين الخاصة التابعة لإدارة التعليم الخاص في العاصمة عدان، خلال الفصل الدر اسي الثاني للعام 2019/2018، واختيرت المدرسة قصدياً؛ لتوفر الظروف الملائمة لتطبق الدر اسة من مثل: توفر مختبرات حاسوب بشكل كاف للطنبة، وتجانس الطلبة بشكل عام في العو امل الاجتماعية والاقتصدادية، وسهولة الحصول على مو افقة المدرسة لإجر اء الأر استة. وقد اختيرت ثلاث شعب للصف الثامن بو اقع (30) طالباً في كل منها، و عينت عشو ائياً في ثلات مجموعات هي: شعبة (أ) مثلّت المجموعة التجريبية الأولى، ودرست المادة التعليمية بالرحلات المعرفية، و الثُعبة (ب) مثلّت المجموعة التجريبية الثانية، ودرست المادة التعليمية بالمنصات التعليمية. أما الثعبة (ج) الثالثة فمثلت المجموعة الضابطة، ودرست المادة التعليمية بالطريقة الاعتيادية. أدوات الدراسةة: اختبار التفكير التأملي لقياس مهار ات التفكير التأملي لدى طلاب الصف الثامن الأساسي في مادة الرياضيات بوحدة المجسمات؛ تمّ إعداد اختبار من نوع الاختيار من متعدد بأربعة بدائل، وقد اتبع في بنائه الخطوات الآتية: 1- الاطلاع على الأدب التزبوي المتصل بموضوع التفكير التأملي، وبخاصة الدراسات السابقة التي استخدمت مقاييس مشابهة في مهار ات التفكير التأملي كدر استة عفانة و اللولو (2002). 2- تحديد الغرض من الاختبار: إذ هدف الاختبار إلى قياس خمس مهارات للتفكير التأملي المحدد بـ: (التأمل و الملاحظة، الكثف عن المغالطات، إعطاء تفسير ات مقنعه، الوصول إلى استتاجات، وضع حلول مقترحة) لدى طلاب الصف الثامن الأساسي في وحدة (المجسمات) من كتاب الرياضيات لهذا الصف. 3- صياغة فقرات الاختبار : جرى صباغة فقرات الاختبر من نوع الاختبار من متعدد على صورة مشكلة أو صورة أو عبارة مفردة تتصل بموضوع من موضوعات المحتوى التعليمي لوحدة المجسمات، ويندرج تحتها أربعة بدائل تقيس إحدى مهار ات التفكير التأملي المحدد مسبقا، وقد روعي في الاختبار سهولة اللغنة، ووضوح العبارات، وملائتها لمستوى الطلاب وللمهار ات المحددة. 4- إعداد الاختبار بصورته الأولية: جرى بناء الاختبار بصورته الأولية مشتملاً على (25) فقرة موزعة على المهار ات الخمسة للتفكير التأملي، بواقع (5) أسئلة لكل مهارة. 5- كتابة تعليمات الاختبار: جرى وضع نعليمات الاختبار في صفحة منفردة هي الصفحة الأولى من ورقة الأسئلة، روعي فيها تحديد هدف الاختبار، وكيفية الإجابة على فقر أته. وبعد أن تم إعداد فقرات الاختبار بصورتها النهائية طبق بصورة إستطلاعية على عينة من الطلبة خارج عينة الدراسة وذلك للتحديد زمن الاختبار و التأكد من طريقة تصحيدة. وظهر ذلك الك واضحا في الصورة النهائية للاختبار . 
جرى التثبت من صدق اختبار التقكير التأملي بطريقتين هـا: 1- - صدق المحتوى: بغرض التأكد من صدق اختبار التفكير التأملي جرى عرضده على عدد من مجموعة من الثُحكِّين المتخصصين في مناهج الرياضيات وتدريسها، و القياس و التقويم في الجامعات الأردنية. 2- - صدق البناء: جرى التحقق من الصدق البنائي لاختبار التفكير التأملي بحساب معامل ارتباط بيرسون بين درجة الفقرة مع الدرجة الكلية للاختبار ، وبين درجة الفقرة مع المجال الذي تتنمي إليه الفقرة، والجدول (1) يبين النتائج. الجدول1 معاملات ارتباط فقرات اختبار التفكير التأملي مع الدرجة الكلية والمجال الذبي تتنمي إليه

\begin{tabular}{|c|c|c|c|c|c|}
\hline معامل الارتباط مع & معامل الارتباط مع & رقام & معامل الارتباط & معامل الارتباط مع & رقم \\
\hline $0.403 * *$ & $0.563^{* *}$ & 11 & $0.330 * *$ & $0.390 * *$ & 1 \\
\hline $0.473^{* *}$ & $0.776^{* *}$ & 12 & $0.373^{* *}$ & $0.427^{* *}$ & 2 \\
\hline $0.536 * *$ & $0.714^{* *}$ & 13 & $0.381^{* *}$ & $0.477 * *$ & 3 \\
\hline $0.426 * *$ & $0.788 * *$ & 14 & $0.416^{* *}$ & $0.487 * *$ & 4 \\
\hline $0.555^{* *}$ & $0.744 * *$ & 15 & $0.414^{* *}$ & $0.647 * *$ & 5 \\
\hline $0.405^{* *}$ & $0.400 * *$ & 16 & $0.317^{* *}$ & $0.418 * *$ & 6 \\
\hline $0.499 * *$ & $0.540 * *$ & 17 & $0.389 * *$ & $0.481 * *$ & 7 \\
\hline $0.435^{* *}$ & $0.459 * *$ & 18 & $0.339 * *$ & $0.493 * *$ & 8 \\
\hline $0.419 * *$ & $0.466 * *$ & 19 & $0.358^{* *}$ & $0.538 * *$ & 9 \\
\hline $0.543^{* *}$ & $0.567 * *$ & 20 & $0.407 * *$ & $0.602 * *$ & 10 \\
\hline
\end{tabular}

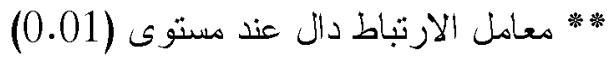

يُلاحظ من الجدول (1) أنَّ معاملات ارنباط فقرات اختبار التفكير التأملي بالدرجة الكلية، والمجال الذي تتنمي إليه كانت إيجابية، ودالة إحصدائيا؛ مما يدل على وجود الصدق البنائي للاختبار . ثبات الاختبار

جرى التنأكد من ثبات اختبار التفكير التثأملي بطريقة طريقة الاختبار وإعادة الاختبار (test - retest)، إذ قام الباحثان بتطبيق الاختبار على عينة استطلاعبة مكونة من (30) طالباً من خارج عيّة الدّراسة ومن مجتمعها بفاصل زمني مدته أسبوعان بين مرَّتي التطبيق، وجرى حساب معامل ثبات الاستقرار باستخدام علاقة معامل ارتباط بيرسون، كما استخدم الباحثان معادلة كيودر - ريتثارد سون - 20 (K- R- 20) لحساب معامل ثبات الاتساق الداخلي للاختبار ، والجدول (2) يُيين معاملات الثبات لاختبار التقكير التأملي. الجدول 2 معاملات الثبات لاختبار التفكير التأملي 


\begin{tabular}{|c|c|c|}
\hline$K-R-20$ & معامل ارتباط بيزسون & المهارة \\
\hline 0.83 & 0.80 & التأمل و المهلاحظة \\
\hline 0.85 & 0.84 & الكثف عن المغالطات \\
\hline 0.81 & 0.85 & الوصول إلى استتتاجات \\
\hline 0.85 & 0.79 & اعطاء تقسير ات مقنعة \\
\hline 0.87 & 0.82 & وضع حلون مقترحة \\
\hline 0.88 & 0.86 & الثبات الكلي للاختبار \\
\hline
\end{tabular}

يُلاحظ من الجدول (2) أن معاملات ثبات الاستقر ار لاختبار التفكير التأملي بطريقة الاختبار ، وإعادة الاختبار تراوحت بين (0.79-0.85) لمجالات الاختبار الخمسة، فيما بلغ معامل الثبات للاختبار ككل (0.86)، وتراوحت معاملات ثبات الاتتاق الداخلي باستخدام معادلة كيودر - ريتشارد سون - 20 بين (0.81-0.87) لمجالات الاختبار الخمسة، فيما بلغ معامل الثبات للاختبار ككل (0.88)؛ وتُعدّ هذه القيم مقبولة لأغر اض الدر اسة الحالية.

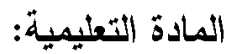

تألف المحتوى التعليمي للرحلات المعرفية و المنصدات التعليمية من مجموعة من الخبرات و المعارف والأنثطة المنتظمة و المتسلسلة في مادة الرياضيات في وحدة (المجسات) للصف الثنامن الأساسي، وجرى تحويل المحتوى المعرفي إلى محتوى رقمي بإعداد فيديوهات شارحة للففاهيم و التعميمات المتضدنة، و اثر ائها بمو اقع إلكترونية تُني الثشرح، وتدريب الطلاب ذاتياً على المهارات المتضدنة، وبناء أنشطة تفاعلية باستخدام جيوجبرا (GeoGebra) للمُساعدة على توضيح العلاقات بين المجسمات، وتسهل استتاج قواعد المساحة الجانبية وانكلية والحجم، وقد جرى تصميمها من فبل الباحثين، وبمساعدة بعض خبراء المنصدات التعليمية لتقديمها إلى الطلاب بصورة مشوقة مصحوبة باللون والصورة والحركة، بالاعتماد على منصدة موودل (MOODLE) التحليمية التي توفر مزايا عدة للمتعلم، فهي منصد لإدارة التعلم بشكل عام، ولعل من أهم ميزات تللك المنصدات تحميل الفيديوهات، وعمل الاختبارات الإلكترونية، وعمل صفوف افتراضية، ونشر أوراق العمل الإكترونية

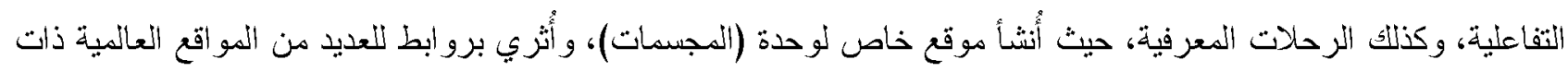
الصلة المباشرة بموضوع وحدة (المجسمات). بناء المادة التعليمية الخاصة بالزحلات المعرفية بعد الاطلاع على الأدب التربوب و الدر اسدات النسابقة التي اهنت ببناء المحتوى التعليمي للرحلات المعرفية، وكذلك التي استخدت نماذج متخصصة كالتي وردت في الدراسات مثل دراسة (عبد الحميد، 2014؛ وصبري والجهني، 2013؛ وسمارة، 2013؛ و الفار، 2011)، بالإضافةٍ إلىى الاطلاع على المعايير التربوية والتقنية لتصميم الرحلات المعرفية والؤردة في (عبد الحمبد، 2014)، وبرنامج مهارات التفكير عبر الإنترنت، في ضوء ذلك اتبع الباحثان المر احل التالية في بناء الوحدة الأرّ اسية الكترونياً (تصميم موفع الرحلة المعرفية في الرياضيات عبر الويب): 1. درحلة التحليل (Analysis): اختار الباحثان الوحدة الثامنة (وحدة المجسمات) من كتاب الزياضيات للصف الثامن 
الأساسي المقرر، وقام بتحليل المحتوى، وتحديد النتاجات الخاصة ضمن الأبعاد المعرفية، والنفسحركية، و اللوجدانية المراد تحقيقها، وذلك بالرجوع إلى دليل المعلم لمادة الرياضيات، وتحديد الخطة الزمنية التي بستغرقها الطلاب في دراسة هذه الوحدة، بالإضدافة إلى تحديد أدوات التقويم المناسبة. 2. مرحة التصديم (:Design): قام الباحثان بوضع الإجراءات التفصيلية على الورق لما سيتم عرضده في الرحلة المعرفية عبر الويب، ثم البحث بالإنترنت للحصول على الصور، والرسومات، ومقاطع القيديو من اليوتيوب، وتحديد المصادر الإكترونية، والتأكد منها، والتتي قد تستخدم في تصميم الرحلة المعرفية عبر الويب، وقد قام بتصميم الرحلة المعرفية عبر الويب مستعيناً ببرمجيات الكامتازيا، و الجيوجبر ا ، ومواقع (zunal.com)، وقد صمدت صفحات الموقع بحسب عناصر

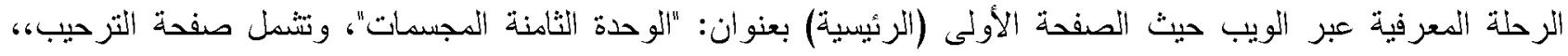
وتحنوي كلمة ترحيبية، و النتاجات المتوقعة، والثانية المقدمة، وتحتوي التعريف بالدجسمات، و الثالثة المهمات، وهي المعلومات التي يحصل عليها الطلاب من خلال الإبحار عبر الثبكة، والز ابعة العمليات (العمليات، والأنشطة التي سبمارسها الطلاب)، و الخامسة معأير التقيم، وهي المعأير التي يستند إليها المقيم في سلم التقدير اللفظي، وكذلك سلم للتقدير اللفظي، و النسادسة الاستتتاج، وفيها أهم الاستنتاجات في كل رحلة، و السابعة صفحة المعلم. 3. مرحلة الإنتاج (Production):؛ وهي تحويل الإجراءات التفصيلية من الؤرق إلى الحاسوب باستخدام البزمجيات اللازمة، إذ جرى حوسبة هذا المحتوى بعمل القيديوهات، والمو اقع الإكترونية الثارحة ذات الصلة بموضوع المادة، وجرى تصميمها بصورة مشوقة بمساعدة بعض خبر اء الزححلات المعرفية لتقدم للطلاب بصورة مشوقة مصحوبة بالألو ان، و الصورة، و الحركة، ثم رفعها إلى موفع http://zunal.com الذي يتيح إنثاء مواقع إلكترونية، وصفحات، وجرى اختيار موقع الزحلة المعرفية (http://zunal.com/webquest.php?w=393562)، وقد تضمن الموفع جميع عناصر الرحلة الوارد ذكرها سابقاً، و أصبح منشوراً على الإنترنت. 4. مرحلة التقويم (Evaluation):، وبعد الإنتهاء من تصميم الوحدة الدّرّاسية إلكترونياً (الوحدة الثامنة المجسمات) تم عرضها بصورتها الأولية على (12) محكماً من المتخصصين في تكنولوجيا التعليم، وبخاصة تصديم المواقع الإكترونية التعليمية، وأسلاليب تدريس الرياضيات، و المشرفين التربويين الحاصلين على دورات تدرييية في مجال توظيف التكنولوجيا في التدريس للوقوف على صلاحيتها، وفق قائمة معايير تقويم، وطُب منهم تقويم كلاً من النصوص، و المحتوى الإكتروني، و الأنثطة المر افقة، و التصديم، والازتباطات التتعبية، ومر اعاتها للمعايير التعليمية، والتربوية، و الفنية، وبناءً على مقترحات، وملاحظات المكمين، وتمّ إجراء بعض التعديلات المناسبة، وقد أكدوا على صدلاحية الموقع وجودته. 5. مرحلة التجريب (Implementation): قام الباحثان بتجريب موقع الرحلات المعرفية عبر الويب على مجموعة من الطلاب للوقوف على سهولة الدخول للموقع، والتتقل بين صفحاته، واستخدام جميع عناصر الرحلة المعرفية عبر الويب، وتحديد المشكلات التي من الممكن أن تواجه الطلاب عند استخدامها، وقد تبين بعد النطبيق الاستطلاعي للرحلة عدم وجود صعوبات تذكر عند الدخول لها، وتصفح صفحاتها، و استخدام عناصر ها، وخلوها من عيوب البرمجة. 
6. مرحلة التدريب على التثريس: إذ جرى عقد جلسات تدريية للمعلمة المطبقة التي ستشرس، وفق الرحلات

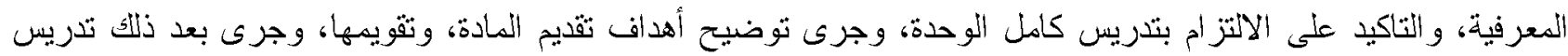
طلاب المجموعة التجريبية الأولى بالزحلات المعرفية؛ وفق الآتي:

$$
\text { 2- تحديد أهداف الدرس. }
$$

3- توضيح للطلاب كيفية الاخول إنى عنو ان الرحلة المعرفية.

4- استخدام المصادر، و الأثثطة المحددة من قبل المعلم.

5- حل ورقة العمل المعدة من قبل المعلم.

6- إدارة النقاش الصفي أثناء العمل.

7- تقديم التخذية الز اجعه للطلاب.

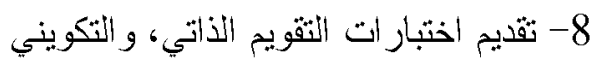

بناء المادة التعليمية الخاصة بالمنصات التعليمية

تألف المحتوى من مجمو عة من الخبر ات، و المعارف، و الأنشطة المنظظمة، والكتسلسلة في مادة الرياضيات في وحدة

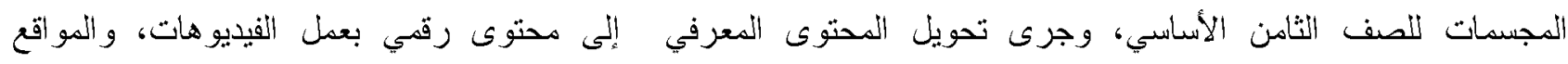
الإكترونية الثارحة ذات العلاقة بموضوع المادة، وجرى تصميمها من قبل الباحثين، وبمساعدة بعض خبرات المنصات التهات

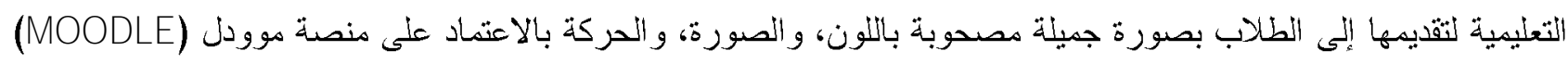

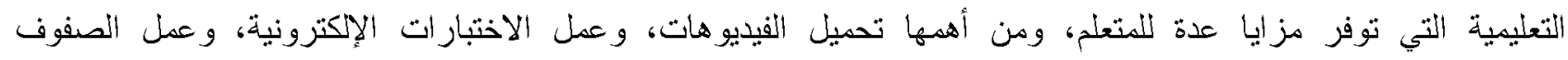

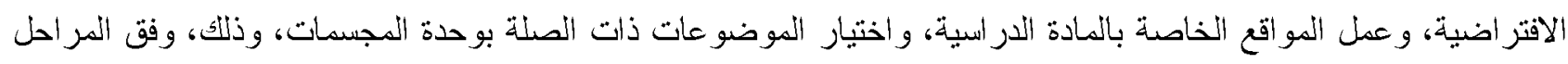

1)مرحلة اختيار المادة التعليمية : تككونت المادة التعليمية من مادة وحدة المجسمات من كتاب الرياضيات للصف الثامن

الأساسي، و أشتملت على الموضوعات الثالية:

\begin{tabular}{|c|c|}
\hline ا الثشبكات. & الدرس الأول \\
\hline جمع المنشور الثلاثي، ومساحة سطحه. & الأل الترس الثاني \\
\hline حجم الأسطو انة، ومساحة سطحها. & الدرس الثالث \\
\hline حجم الكخروط، ومساحه سطده. & الدرس الر ابع \\
\hline حجم الهرم، ومساحة سطده. & الدرس الخامس \\
\hline حجم الكرة، ومساحة سطحها. & الدرس السادس \\
\hline معامل التغير. & الدرس السابع \\
\hline
\end{tabular}

الجدول 3 موضو عات الوحدة الثامنة (المجسمات) 
2) مرحلة بناء المادة التعليمية: حيث جرى بناء الوحدة بأساليب متعددة باستخدام برمجية الكمتازيا، وبرمجية الجيوجبر ا، وجرى تسجيل القيديو هات الثـارحة ذات الصلة بموضوع المادة، حيث تم تصديمها بمساعدة بعض خبر اء المنصات التعليمية، ووضعها على منصدة (MOODLE) الخاصة بمدرسة الناصر الحديثة مكان التطبيق لتقدم للطلاب بصورة مشوقة مصحوبة بالألوان، والصورة، والحركة، ووضعها مع الأنشطة، والواجبات، وأور اق العمل المناسبة ليسهل استخدامها من قبل الطلاب.

3) مرحلة تحكيم المنصدات التعليمية: حيث جرى عرض المحتوى التعليمي المصدم للتدريس بالمنصات التعليمية على مجموعة من المحكمين من أعضاء هيئة التدريس، وإجر اء التعديلات المناسبة في ضوء توجيهاتهه، وبذلك أصبح في صورته النهائية صدالحاً للاستخدام.

4- مرحلة تجريب المنصات التعليمية: حيث جرى تجريب موقع المنصة على عينة من (6) طلاب من مجتمع الدر اسة وخارج عينتها، و الحصول على التخذية الز اجعه في أثناء علية التطبيق حول مدى سهولة الاستخدام بو اسطة جهاز الحاسوب. 5- مرحلة التدريب على التدريس: إذ جرى عقد جلسات تدريبية للمعلمة المطبقة التي ستدرس المحتوى التعليهي وفق المنصات التعليمية، و التأكيد على الالتزام بتدريس كامل الوحدة بهذه الطريقة، وجزى توضيح أهداف تقديم المادة، وتثويمها. وجرى بعد ذللك تدريس طلاب المجموعة التجريبية الثانبة بالمنصدات التعليمية، وقد سارت عملية التدريس للمجموعة التجرييية الثانية، وفق الآثي:

$$
\text { 1- توضيح نتاجات الدروس. }
$$

2- التأكد من عمل اللوح الإكتروني.

3- تدريب الطلاب على كيفية التعامل مع المنصات التعليمية. 4- تدريب الطلاب على كيفية مشاهدة الفيديوهات الثشارحة، وعمل التقويم الذاتي في النيت.

5- ممارسة النشاطات باستخدام برمجة جيوجبرا (GeoGebra). 6- التأكد من صحه الحل خلال مشاهدة الفيديوهات. 7- إدارة النقاش الصفي أثناء العمل. 8- استخدام أور اق عمل مناسبة للطلاب. 9- تقديم التغذية الر اجعة للطلاب. 10- متابعة الطلاب من خلال التقارير الإكترونية.

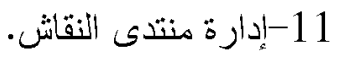

$$
\text { 12-12-إجر اء حصص إفتر اضية عبر (zoom). }
$$

بغرض الإجابة عن أسئلة الار اسة، واختبار فرضياتها، اعتمد تصميم الهجموعات غير المتكافئة باختبار قبلي، وبعدي، ويمن التعبير عن هذا التصميم التجريبي بالزموز على النحو الآتي: 


\begin{tabular}{|c|c|c|c|}
\hline$E G 1$ & 01 & $X 1$ & 01 \\
\hline$E G 2$ & 01 & $X 2$ & 01 \\
\hline$C G$ & 01 & - & 01 \\
\hline
\end{tabular}

وقد تم ضبط عدم تكافؤ المجموعات بالاختبار الإحصائي. حيث أند يتعذر في ظروف التطبيق إعادة توزيع الطلبة إلى مجمو عات متكافئة. حيث ترمز : EG1 EG2 CG X1 X1 التدريس باستخدام الرحلات المعرفية. X2 X2 التدريس باستخدام المنصدات التعليمية.

: 01: القياس القبلي والبعدي باستخدام اختبار التفكير التأملي. المعالجة الإحصائية

بغرض الإجابة عن أسئلة الدراسة جرى استخدام الطرق الإحصائية الآثية:- المتوسطات الحسابية، والانحر افات المعيارية لأداء الطلاب على اختبار التفكير التأملي. - تحليل التباين الأحادب المصاحب (ANCOVA)، و تحليل النباين الأحادي المصاحب المتعدد (MANCOVA) للإجابة عن السؤالين الأول الثناني المتعلقين باختبار التفكير التأملي. - ريتشارد سون - 20 (K- R- 20) للتحقق من ثبات اختبار التفكير التأملي. نتائج الار اسة

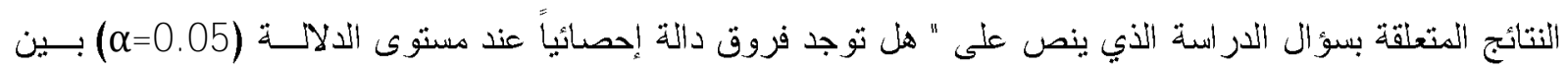

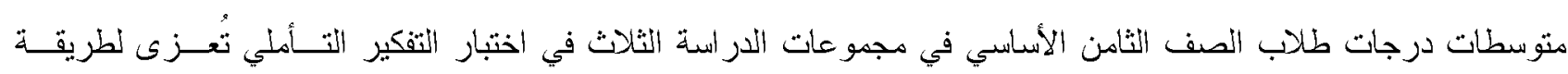
التدريس (الرحلات المعرفية، المنصات التعليمية، الطريقة الاعتيادية)": للإجابة عن هذا السؤال جرى حساب المتوسطات الحسابية والانحر افات المعيازية لأداء أفر اد مجموعات الدر استة فــي اختبار التفكير التأملي في التطبيقين القبلي و البعدي، والجدول (4) يُيين ذلك. 
الجدول 4 المتوسطات الحسابية، والاندر افات المعيارية لأداء أفر اد مجموعات الدراسة في اختبار التفكير التأملي البعدي في التطبيقين القبلي و البعدي

\begin{tabular}{|c|c|c|c|c|c|c|}
\hline \multicolumn{2}{|c|}{ الاختبار البعدي } & \multicolumn{2}{|c|}{ الاختبار القبلي } & \multirow{2}{*}{ الالارجة } & \multirow[b]{2}{*}{ العدد } & \multirow[b]{2}{*}{ المجموعة } \\
\hline الآمر اف & المستوسط & الاحمراف & المستوسط & & & \\
\hline 1.41 & 11.93 & 2.04 & 8.20 & \multirow{3}{*}{20} & 30 & الضـابطة \\
\hline 2.24 & 15.13 & 2.94 & 7.30 & & 30 & الرحلات المعرفية \\
\hline 1.77 & 17.97 & 2.77 & 8.70 & & 30 & المنصات التعليمية \\
\hline
\end{tabular}

يُلاحظ من الجدول (5) أنَّ المتوسط الحسابي لأداء أفر اد المجموعة التجريبية الثانية في اختبار التفكير التأملي البعـدبي

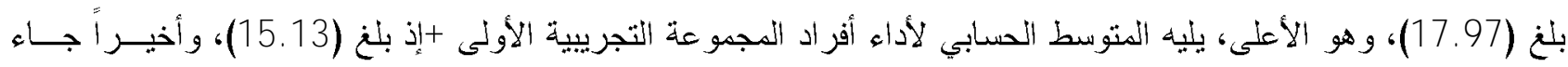
المتوسط الحسابي لأداء أفر اد المجموعة الضدابطة الذين درسوا بالطريقة الاعتبادية إذ بلغ (11.93)، ولمعرفة هــا إذا كانست

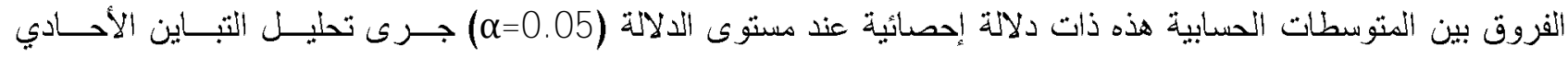
المصداحب (ANCOVA)، و الجدول (5) ييين نتائج التحليل. الجدول 5 نتائج تحليل التباين الأحادي المصاحب (ANCOVA) لأداء أفر اد مجموعات الدر اسة في اختبار التفكير التأملي البعدي

\begin{tabular}{|c|c|c|c|c|c|c|}
\hline حجم الأثر & مستوى & |قيمة ف & متوسط المربعات & الحرية & المربعات & مصدر التباين \\
\hline 0.000 & 0.984 & 0.000 & 0.001 & 1 & 0.001 & الاختبار القبلي \\
\hline \multirow[t]{3}{*}{0.649} & 0.000 & 79.465 & 271.935 & 2 & 543.87 & طريقة التدريس \\
\hline & & & 3.422 & 86 & 294.299 & الخطاً \\
\hline & & & & 89 & 840.989 & كلي المعدل \\
\hline
\end{tabular}

يُلاحظ من الجدول (5) أنَّ قيمة (ف) بالنسبــة إلىى طريقة التدريس بلغــت (79.465)، وبمسـتوى دلالــة يسـاوي (0.000)، مما يدل على وجود فروق ذات دلالة إحصائية بين متوسطات أداء مجموعات الدراسة في اختبار التفكير التـأملي البعدي.

ولصالح أي المجموعات كانت هذه الفروق في حالة وجود الدلالة جرى استخر اج المتوسطات الحسابية المعدلة، والخطأ المعياري للمجموعات الثثلاث في اختبار التفكير التأملي، والتي تظهر في الجدول (6). الجدول 6 المتوسطات الحسابية المعدلة، والأخطاء المعيارية لأداء أفر اد مجموعات الدراسة في اختبار التفكير التأملي البعدي 


\begin{tabular}{|c|c|c|}
\hline الخطأ المعياري & المتوسط الحسابي المعلل & المجموعة \\
\hline 0.34 & 11.93 & الضدابطة (الاعتبادية) \\
\hline 0.34 & 15.13 & الرحلات المعرفية \\
\hline 0.34 & 17.97 & المنسـات التعلبمية \\
\hline
\end{tabular}

يُّلاحظ من الجدول(6) أنَّ المتوسط الحسابي المعدل لأداء أفر اد المجموعة التجريبية الثانية في اختبار التفكير التهأملي

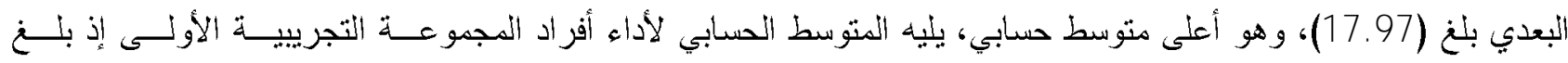

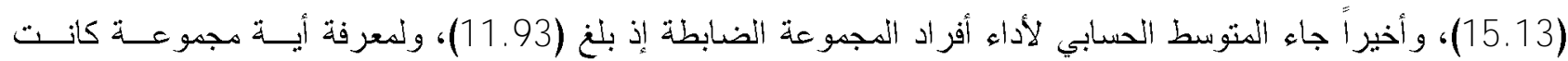
الفروق بين الكتوسطات الحسابية جرى تطبيق اختبار شيفيه للمقارنات البعدية، والجدول (7) يبين نتائج ذلك.

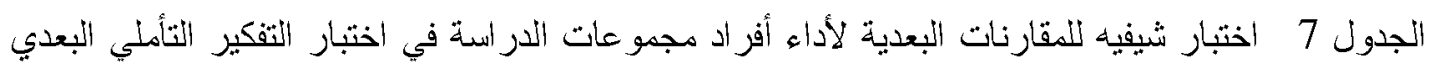

\begin{tabular}{|c|c|c|c|c|}
\hline الضابطة & الرحعلات & التعليمية & \multirow[t]{2}{*}{ |المتوسط الحسابي } & \multirow[t]{2}{*}{ المجموعة } \\
\hline 11.93 & 15.13 & 17.97 & & \\
\hline$* 6.04$ & $* 2.84$ & - & 17.97 & الكنصدات التعليمية \\
\hline$* 3.2$ & - & & 15.13 & الرحلات المعرفية \\
\hline- & & & 11.93 & الضابطة (الاعتيادية) \\
\hline
\end{tabular}

(الفرق دال إحصائياً عند (م=0.05)

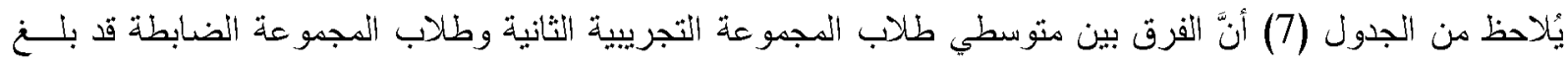

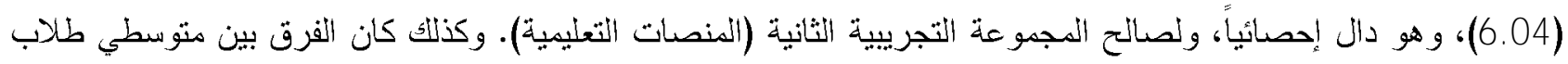

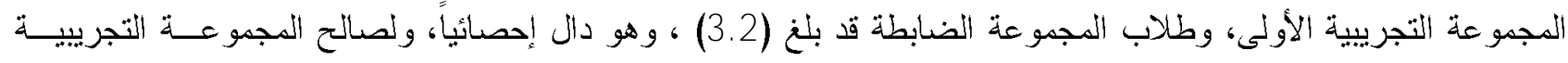

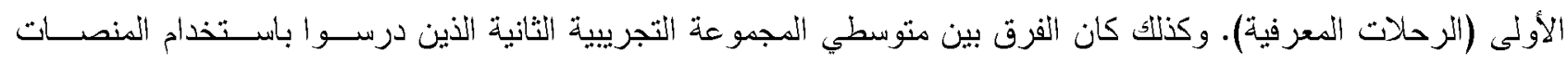

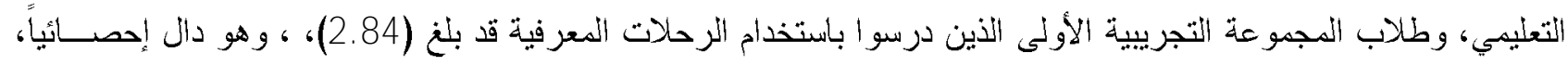

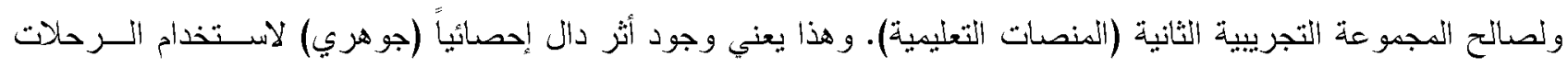
المعرفية، والمنصات التعليمية في تدريس مبحث الرياضيات في اختبار القوة التفكير التأملي لدى طلاب الصف الثامن الأساسي الثيا في الأردن.

ولتحديد حجم الأثَر جرى حساب مؤشر حجم الأثر مربع إيتا (Eta Squared) إذ بلغ (0.649)، ما يعنسي أن نسـبة

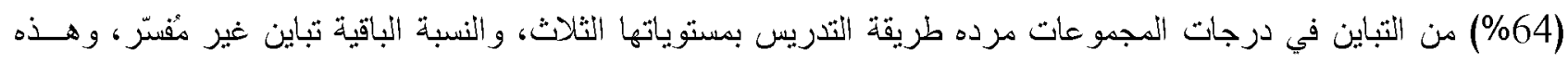

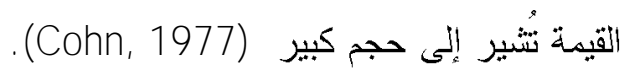
ولمعرفة أثز كل من الرحلات المعرفية، والمنصات التعليمية في مهارات التفكير التأملي الخس : (التأمل والملاحظة، الكثف عن المغالطات، الوصول إلى استتاجات، أسباب مقنعة، الوصول إلى حلول) قام الباحثان بحساب المتوسطات الحسابية، 922 IUG Journal of Educational and Psychology Sciences (Islamic University of Gaza) / CC BY 4.0 
و الانحر افات المعيارية لأداء أفراد مجموعات الدراسة على مهارات اختبار التفكير الثأملي في التطبيقين القبلي والبعـدي لهــا الاختبار ، والجدول (8) ييين ذلكك. الجدول 8 الكتوسطات الحسابية، والانحر افات المعيارية لأداء أفراد الدراسة على مهارات اختبار التفكير التأملي البعدي

\begin{tabular}{|c|c|c|c|c|c|c|}
\hline \multicolumn{7}{|c|}{ والقب: } \\
\hline \multicolumn{2}{|c|}{ الاختبار البعدي } & \multicolumn{2}{|c|}{ الاختبار القبلي } & \multirow[b]{2}{*}{ العدد } & \multirow[b]{2}{*}{ المجموعة } & \multirow[b]{2}{*}{ المهارة } \\
\hline الاحعراف & الحسابي & الالمعراف & الحسابي & & & \\
\hline 0.82 & 2.43 & 0.80 & 2.33 & 30 & الضابطة & \multirow{3}{*}{ تأمل و الملاحظة } \\
\hline 1.08 & 2.93 & 1.38 & 2.20 & 30 & الزحلات المعرفية & \\
\hline 0.65 & 3.70 & 1.19 & 2.63 & 30 & الدنصات النتعليمية & \\
\hline 0.73 & 2.77 & 0.96 & 1.80 & 30 & الضابطة & \multirow{3}{*}{ كثثف عن المغالطات } \\
\hline 0.97 & 3.43 & 1.19 & 1.37 & 30 & الرحلات المعر فية & \\
\hline 0.43 & 3.87 & 1.07 & 1.97 & 30 & المنصات التعليمية & \\
\hline 0.66 & 2.10 & 0.77 & 1.40 & 30 & الضابطة & \multirow{3}{*}{ لوصول إلى استثتاجات } \\
\hline 1.14 & 2.93 & 0.92 & 1.30 & 30 & الرحلات المعر فية & \\
\hline 0.73 & 3.50 & 0.90 & 1.53 & 30 & المنصات النتعليمية & \\
\hline 0.79 & 2.30 & 0.84 & 1.67 & 30 & الضـابطة & \multirow{3}{*}{ اعطاء تفسيرات مقتعة } \\
\hline 0.90 & 2.87 & 1.03 & 1.33 & 30 & الرحلات المعر فية & \\
\hline 0.86 & 3.43 & 0.94 & 1.47 & 30 & الكنصات التعليمية & \\
\hline 1.03 & 2.33 & 0.98 & 1.00 & 30 & الضـابطة & \multirow{3}{*}{ وضع حلول مقترحة } \\
\hline 0.92 & 2.90 & 0.71 & 1.10 & 30 & الرحلات المعرفية & \\
\hline 0.82 & 3.47 & 0.71 & 1.10 & 30 & المنصات التعليمية & \\
\hline
\end{tabular}

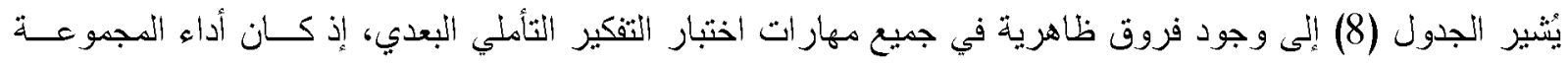
التجريية الثانية أعلى من أداء الدجموعة التجرييية الأولى التي درست ، وأعلى كذللك من أداء أفر اد المجموعة الضدابطة التي

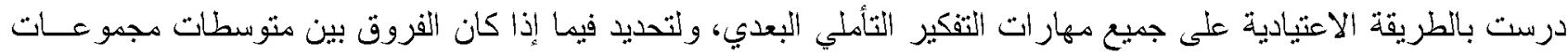

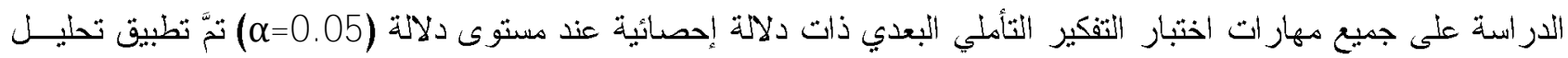
التباين المصاحب (MANCOVA)، وجاءت نتائج التحليل على النحو الذي يوضده الجدول (9). الجدول 9 تحليل التباين المصاحب منعدد التنغيرات التابعة (MANCOVA)لأداء أفراد الدراسة على مهار ات اختبار التفكير التأملي البعدي 


\begin{tabular}{|c|c|c|c|c|c|c|c|c|}
\hline $\begin{array}{c}\text { قيمة } \\
\text { Wilks' } \\
\text { Lambd }\end{array}$ & الأثر & مستوى & ثيمة ف المحسوبة & متوسط & الحرية & مجموع & \multirow[t]{2}{*}{ المهارة } & \multirow[t]{2}{*}{ مصدر التباين } \\
\hline a & & & & & & & & \\
\hline \multirow{5}{*}{0.312} & 0.008 & 0.412 & 0.679 & 0.468 & 1 & 0.468 & التأمل و الملاحظة & \multirow{5}{*}{ و المـلاحظة } \\
\hline & 0.000 & 0.920 & 0.010 & 0.006 & 1 & 0.006 & الكثنف عن المغالطات & \\
\hline & 0.003 & 0.602 & 0.274 & 0.217 & 1 & 0.217 & الوصول إلى استتتاجات & \\
\hline & 0.003 & 0.600 & 0.277 & 0.201 & 1 & 0.201 & اعطاء تفسير ات مقنعة & \\
\hline & 0.001 & 0.769 & 0.086 & 0.076 & 1 & 0.076 & وضع حلول مقترحة & \\
\hline \multirow{5}{*}{1.692} & 0.060 & 0.025 & 5.238 & 3.608 & 1 & 3.608 & التأمل و المدلاحظة & \multirow{5}{*}{ الكثف عن } \\
\hline & 0.011 & 0.351 & 0.881 & 0.499 & 1 & 0.499 & |اكتثف عن المغالطات & \\
\hline & 0.005 & 0.504 & 0.450 & 0.356 & 1 & 0.356 & الوصول إلى استتاجات & \\
\hline & 0.027 & 0.136 & 2.264 & 1.644 & 1 & 1.644 & اعطاء تفسير ات مقنعة & \\
\hline & 0.004 & 0.547 & 0.366 & 0.322 & 1 & 0.322 & وضع حلول مقترحة & \\
\hline \multirow{5}{*}{1.364} & 0.069 & 0.016 & 6.101 & 4.203 & 1 & 4.203 & |التأمل و المـلاحظة & \multirow{5}{*}{ الوصول إلى } \\
\hline & 0.001 & 0.775 & 0.082 & 0.047 & 1 & 0.047 & |اكتثف عن المغالطات & \\
\hline & 0.003 & 0.604 & 0.271 & 0.214 & 1 & 0.214 & الوصول إلىى استتاجات & \\
\hline & 0.003 & 0.649 & 0.209 & 0.152 & 1 & 0.152 & اعطاء تفسير ات مقنعة & \\
\hline & 0.004 & 0.567 & 0.330 & 0.291 & 1 & 0.291 & وضع حلول مقترحة & \\
\hline \multirow{5}{*}{0.811} & 0.004 & 0.561 & 0.341 & 0.235 & 1 & 0.235 & التأمل و المـلاحظة & \multirow{5}{*}{ تفسير ات اعطاء } \\
\hline & 0.019 & 0.213 & 1.574 & 0.892 & 1 & 0.892 & |اكثثف عن المغالطات & \\
\hline & 0.001 & 0.833 & 0.045 & 0.035 & 1 & 0.035 & الوصول إلى استتتاجات & \\
\hline & 0.001 & 0.814 & 0.056 & 0.040 & 1 & 0.040 & اعطاء تفسير ات مقنعة & \\
\hline & 0.027 & 0.133 & 2.303 & 2.028 & 1 & 2.028 & وضدع حلول مقترحة & \\
\hline \multirow{5}{*}{0.563} & 0.007 & 0.440 & 0.603 & 0.415 & 1 & 0.415 & |التأمل و المـلاحظة & \multirow{5}{*}{ وضع حلول } \\
\hline & 0.004 & 0.557 & 0.348 & 0.197 & 1 & 0.197 & |الكثف عن المغالطات & \\
\hline & 0.012 & 0.320 & 1.002 & 0.792 & 1 & 0.792 & الوصول إلى استنتاجات & \\
\hline & 0.003 & 0.637 & 0.224 & 0.163 & 1 & 0.163 & اعطاء تفسير ات مقنعة & \\
\hline & 0.000 & 0.874 & 0.025 & 0.022 & 1 & 0.022 & وضع حلول مقترحة & \\
\hline
\end{tabular}




\begin{tabular}{|c|c|c|c|c|c|c|c|c|}
\hline \multirow{15}{*}{11.247} & 0.298 & 0.000 & 17.368 & 11.965 & 2 & 23.929 & |التأمل و الماحظة & \multirow{5}{*}{ طريقة } \\
\hline & 0.293 & 0.000 & 17.021 & 9.649 & 2 & 19.297 & |الكثف عن المغالطات & \\
\hline & \begin{tabular}{l|l}
7 & 0.312
\end{tabular} & 0.000 & 18.611 & 14.710 & 2 & 29.420 & الوصول إلى استتتاجات & \\
\hline & 0.231 & 0.000 & 12.324 & 8.948 & 2 & 17.897 & اعطاء تفسير ات مقنعة & \\
\hline & 0.200 & 0.000 & 10.236 & 9.011 & 2 & 18.023 & وضع حلول مقترحة & \\
\hline & & & & 0.689 & 82 & 56.488 & التأمل، و الملاحظة & \\
\hline & & & & 0.567 & 82 & 46.482 & الكثثف عن المغالطات & \\
\hline & & & & 0.790 & 82 & 64.812 & الوصول إلى استتناجات & الخطأ \\
\hline & & & & 0.726 & 82 & 59.538 & اعطاء تفسير ات مقنعة & \\
\hline & & & & 0.880 & 82 & 72.188 & وضع حلول مقترحة & \\
\hline & & & & & 89 & 89.956 & |التأمل و الملاحظة & \\
\hline & & & & & 89 & 66.622 & الكثشف عن المغالطات & \\
\hline & & & & & 89 & 95.822 & الوصول إلى استتتاجات & الكلي المعدل \\
\hline & & & & & 89 & 82.400 & اعطاء تفسير ات مقنعة & \\
\hline & & & & & 89 & 94.100 & وضع حلول مقترحة & \\
\hline
\end{tabular}

يُلاحظ من الجدول (9) أنَّ قيمة ويلكس لامدا (Wilks Lambda) بلغت (11,247) بمستوى دلالة (0.00)، وهي دائة

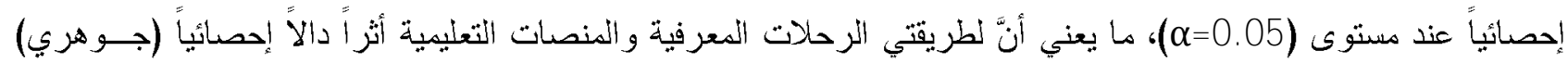

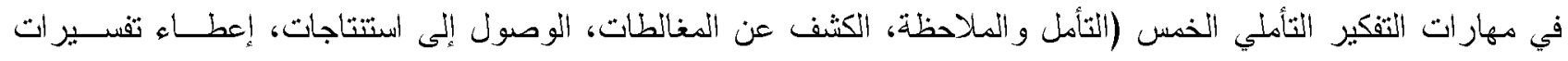
مقنعة، وضع حلول مقترحة).

ولتحديد في أبيّ من هذه المهار كات كان الأثر دالاً إحصائيًاً نتأمل القيم الموجودة في الجدول (9) حيث يُلاحظ أنَّ قيهـة

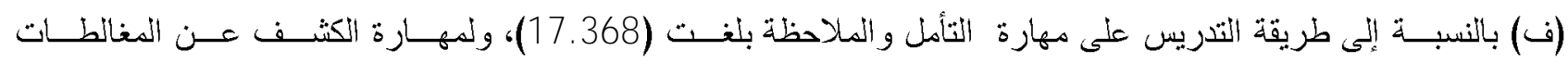

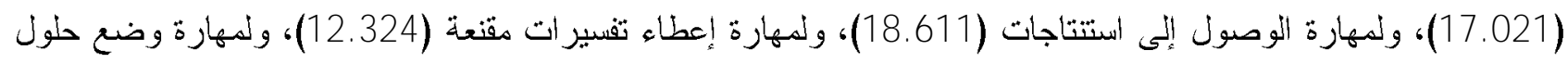

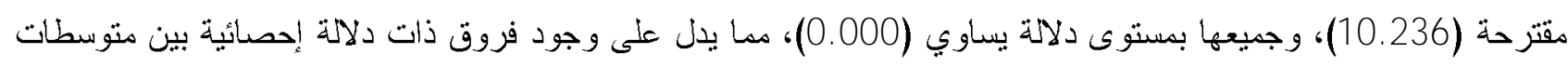

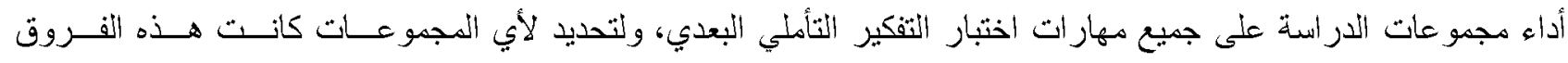
لصالحها جرى استخراج المتوسطات الحسابية المعلة، و التي تظهر في الجدول (10). 
الجدول 10 المتوسطات الحسابية المعدلة، والأخطاء المعيارية لأداء أفر اد مجمو عات الدر اسة على مهار ات اختبار التفكير التأملي البعدي

\begin{tabular}{|c|c|c|c|}
\hline الخطأ المعياري & المتوسط الحسابي المعلل & المجموعة & المهارة \\
\hline 0.15 & 2.44 & | الضدبطة & \multirow{3}{*}{ التأمل و الملاحظة } \\
\hline 0.16 & 2.91 & |الرحلات المعرفية & \\
\hline 0.15 & 3.71 & |المنصات التعليمية & \\
\hline 0.14 & 2.75 & | الضدابطة & \multirow{3}{*}{ الكثف عن المغالطات } \\
\hline 0.14 & 3.43 & |الرحلات المعرفية & \\
\hline 0.14 & 3.89 & |المنصات التعليمية & \\
\hline 0.16 & 2.09 & | الضدابطة & \multirow{3}{*}{ الوصول إلى استتاجات } \\
\hline 0.17 & 2.95 & |الرحلات المعرفية & \\
\hline 0.17 & 3.49 & |المنصات التعليمية & \\
\hline 0.16 & 2.29 & |الضـابطة & \multirow{3}{*}{ إعطلاء تفسير ات مقنعة } \\
\hline 0.16 & 2.92 & |الرحلات المعرفية & \\
\hline 0.16 & 3.39 & |المنصات التعليمية & \\
\hline 0.17 & 2.35 & |الضدابطة & \multirow{3}{*}{ وضع حلول مقترحة } \\
\hline 0.18 & 2.88 & |الرحلات المعرفية & \\
\hline 0.17 & 3.46 & |المنصات التعليمية & \\
\hline
\end{tabular}

يُلاحظ من الجدول (10) أنَّ المتوسطات الحسابية المعدلة لأداء أفر اد المجموعة التجريبية الثانية على جميع مهــارات

اختبار التفكير التأملي البعدي كانت الأعلى، وتليها المتوسطات الحسابية لأداء أفر أد المجموعة التجريبية الأولى ، وأخير جاءت المتوسطات الحسابية لأداء أفرد المجموعة الضابطة ، ولمعرفة أبي المجموعات كان الفرق بـين متوســطاتها الحســابية دالاً

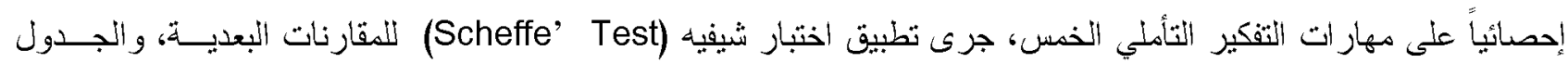
(11) يبين نتاثج التحليل. الجدول 11 اختبار شيفيه للنقارنات البعدية لأداء أفر اد مجموعات الدراسة على مهار ات اختبار التفكير التثألمي البعدي

\begin{tabular}{|c|c|c|c|c|c|}
\hline الضابطة & الرحلات & التعليمية & \multirow{2}{*}{ الحستوسط } & \multirow[t]{2}{*}{ المجموعة } & المهارة \\
\hline 2.44 & 2.91 & 3.71 & & & \multirow[t]{2}{*}{ التأمل و الملاحظة } \\
\hline$* 1.27$ & $* 0.8$ & - & 3.71 & المنصات التعليمية & \\
\hline
\end{tabular}


 \\ أثر استخام الثرحلات المعرفية والمنصات التعليمية في تنمبة التفكير التأملي بمبحث الرياضيات لاى طلاب الصف الثامن}

الأساسي

\begin{tabular}{|c|c|c|c|c|c|}
\hline$* 0.47$ & - & & 2.91 & الرحلات المعرفية & \\
\hline- & & & 2.44 & الضـابطة & \\
\hline الضـابطة & الرحلات & التعليمية & \multirow{2}{*}{ المنوسط } & \multirow[t]{2}{*}{ المجمو عة } & \multirow{5}{*}{ الكثُف عن } \\
\hline 2.75 & 3.43 & 3.89 & & & \\
\hline$* 1.14$ & $* 0.46$ & - & 3.89 & المنصدات التعليمية & \\
\hline$* 0.68$ & - & & 3.43 & الرحلات المعرفية & \\
\hline- & & & 2.75 & الضابطة & \\
\hline الضـابطة & الرحلات & التعليمية & \multirow{2}{*}{ المنوسط } & \multirow[t]{2}{*}{ المجمو عة } & \multirow{5}{*}{ الوصول إلى } \\
\hline 2.09 & 2.95 & 3.49 & & & \\
\hline$* 1.4$ & $* 0.54$ & - & 3.49 & المنصدات التعليمبة & \\
\hline$* 0.86$ & - & & 2.95 & الرحلات المعرفية & \\
\hline- & & & 2.09 & الضـابطة & \\
\hline الضـابطة & المحرلات & التعليمية & \multirow{2}{*}{ المنتوسط } & \multirow[t]{2}{*}{ المجمو عة } & \multirow{5}{*}{ إعطاء تفسير ات } \\
\hline 2.29 & 2.92 & 3.39 & & & \\
\hline$* 1.1$ & $* 0.47$ & - & 3.39 & المنصدات التعليمية & \\
\hline$* 0.63$ & - & & 2.92 & الرحلات المعرفية & \\
\hline- & & & 2.29 & الضـابطة & \\
\hline الضـابطة & الرحلات & التمليميةت & \multirow{2}{*}{ المتوسط } & \multirow[t]{2}{*}{ المجمو عة } & \multirow{5}{*}{ وضع حلول } \\
\hline 2.35 & 2.88 & 3.46 & & & \\
\hline$* 1.11$ & $* 0,58$ & - & 3.46 & المنصدات التعليمية & \\
\hline$* 0.53$ & - & & 2.88 & الرحلات المعرفية & \\
\hline- & & & 2.35 & الضابطة & \\
\hline
\end{tabular}

* الفرق دال إحصدئًا

يلاحظ من الجدول (11) ما يلي: 
- إنَّ هناك فروقاً دانة إحصائياً بين متوسطات أداء المجموعة التجريبية الثانية (المنصدات التعليمية)، وأداء المجموعة الضدبطة (الطريقة الاعتبادية) في جميع ههارات التفكير التأملي الخمس ولصالح المجموعة التجريبية الثانية التي درست وفق المنصدات التعليمية، مقارنة مع المجمو عة الضابطة. - ـونصالح المجموعة التجريبية الأولى عند مقارنتها مع المجموعة الضدابطة، ونصالح المجموعة التجريبية الثانية عند مقارنتها مع المجموعة التجرييية الأولى (الزححلات المعرفية). أظهرت النتائج وجود فروق ذات دلالة إحصائية بين متوسطات أداء مجموعات الدر اسة في اختبار التفكير التأملي ككل، وفي جميع مهار اته الخمس جميعها (التأمل و الملاحظة، الكثف عن المغالطات، الوصول إلى اســتناجات، إعطــاء تفسـيرات مقنعة، وضع حلول مقترحة). إذ وجد أنَّ هنالك فرقاً دالاً إحصائياً بين متوسطي طلاب المجموعة التجرييية الثانية الذين درسوا

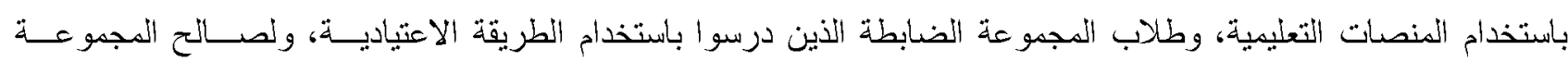
التجرييية الثانية. وأنَّ هنالك فرقاً دالاً إحصائياً بين متوسطي طلاب المجموعة التجرييية الأولى الذين درسوا باستخدام الرحلات

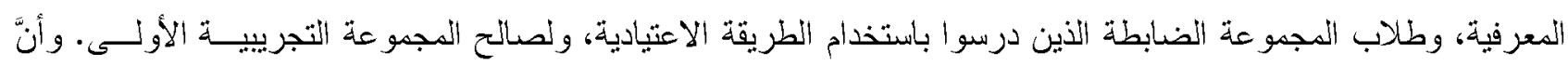

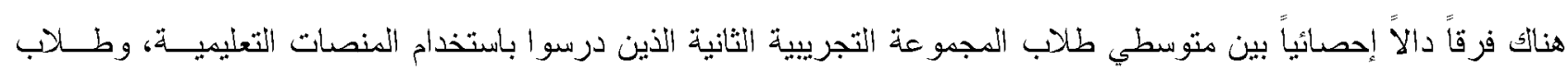
المجموعة التجريبية الأولى الذين درسوا باستخدام الرحلات المعرفية، ولصالح المجموعة التجريبية الثانية، وهذا بعني وجسود

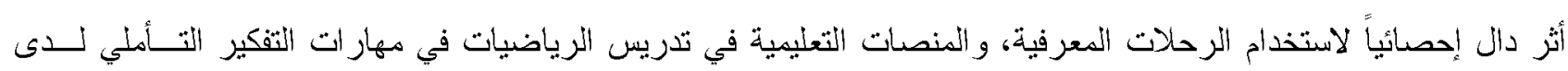
طلاب الصف التامن الأساسي في الأردن. وقد تُعزى هذه النتيجة إلىى أسباب متعددة، منها وجود اللو اجهة الإككترونية، و التتي قدّّت المادة الدر اسية للطلاب بأتشكال مختلفة مثل: (المستتدات، وملفات فيديو تعليمية، و أفلام قصيرة، وعروض تقديمية، وصور ورو ابط إلكترونية، ومحتوى مطبوع ومنظم ومنسق)، يُضاف إلى ذلك أنَّ المنصات التعليمية أشتصلت على محتوى معرفي واضح لدروس المـادة التعليمية الخاصدة بوحدة (المجسمات)، وقد تمَّ عرضها بطريقة منظمة ومتسلسلة داخل المنصات. ومن ناحية أخرى أتاحت هذه الطريقة للطلاب فرصدة مشاركة المعلومات مع بعضهه، ومناقتشها مع إمكانبة التحكم بالمحتوى وتنظيمه وفق قدر ات الطالب ور غباته؛ مما جعل المحتوى ذا معنى للطلاب دفعهم إلى الاهنسام بـ، وفهمه بشكل أكثر عقتاً، وهذا ساعدهم على ربط الخبرات السابقة ذات الصلة بالتعلّم الجديد، وجعهم يتهيؤون عقلياً لاستقبال المفاهيم، و المعلومات ذات الصلة، ومعانجتها، واستدعائها عند الحاجة، وهذه العملية أدت إلى تأمل المعلومات و المفاهيم، وتتمية ههارات التفكير التقأملي لدى الطلاب. وقد تُعزى هذه النتيجة إلى أنَّ المصادر الإضافية الموجودة في المنصات التعليمية، و المرنبطة بالمادة التعليمية عملت على تزويد الطلاب بمعارف، ومهارات إضافية تزيد عما هو موجود في الكتاب المدرسي؛ فأتاحت لهم هذه المعارف، و المهار ات فرص البحث، و الاكتثاف، و التأمل في تلك المفاهيم، بحيث ساعدهم ذلك على النوصل إلى بعض المعارف بأنفهه من خلال عدة مهار ات أساسية للتفكير مثل: التصنيف، والمقارنة، و الترتيب، و التحليل، أدت إلى تتظيم العمليات العقلية بشكل أفضل، و التفكير و التأمل فيها بشكل أوسع، ومثال ذلك أنثطة الجيوجبرا الإضافية على الأسطو انة و المخروط، حيث تمَّ إعطاء 
الطالب حجم معين، ويقوم الطالب بحلّه للوصول إلى استتاجات حول الارتفاع، ومساحة القاعدة، وهي إحدى مهاز ات التفكير التأملي. فضلاً عن أنَّ المنصات التعليمبة قدّت للطلاب أنشطة مُوجِهة تحتوبي على أوراق عمل ترتبط بالمجسمات، وطُب من

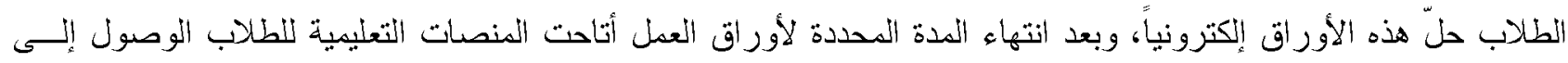
حلول تلك الأور اق إلكترونياً، ساهدت في حصولهم على التغذية الز اجعة، والتأمل فيما قدموه من حلون لتلك الأوراق، وبيـان الإجابات النموذجية، والتعرّت إلى نقاط الضعف، و المفاهيم غير الصحيحة التي وفعوا فيها، و القيام بعمليات تصحيحها، وهـذه العملية زادت من مستوى التفكير التأملي لديهه. إنَّ الميزات التي تتمتع بها المنصدات التعليمية أتاحت قدراً كبيراً من المرونة لكل من المعلم و الطالب في تتظيم المحتوى المعرفي، وإدارة عملية التعلّم بطريقة تفرّد التعليم بشكل أفضل، وقد ظهر ذلك جليًا من خلال تقديم نشاط يُماتل الفقرة الخامسة من اختبار التفكير التأملي، و المتعلقة بخطأ في حساب حجم المخروط؛ حيث أنَّ المعلم نشر على منتى النقاش سؤالاً مثــابهاً، وطُلب من جميع المشاركين التعليق على الخطأ الذبي وقع به في حساب حجم المخروط، وكانت مســاهمات الطـلاب ثريــة، و عكست بشكل و اضح مدى عمق الفهم الذي حصلوه. كما أنَّ هذا الأسلوب أتاح للمعلم، وسهل عليه عملية متابعة الطلاب الذين

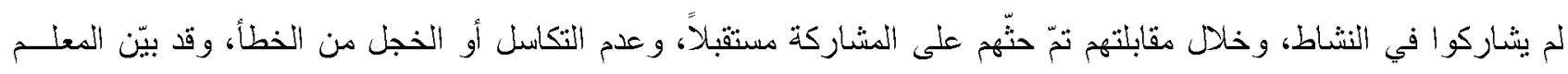
للطلاب أهمية التعلّم من الأخطاء، وتعميق الفهم من خلال التفكير التأملي فيما يقومون به. ومن أسباب ذلك أنَّ المنصدات أتاحت للطلاب توظيف لوح التفاعل الإكتروني أو الكاميرا الموجهة التي تقوم بتسجيل

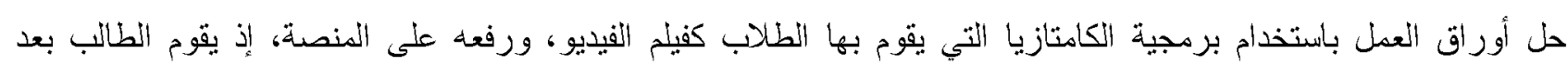

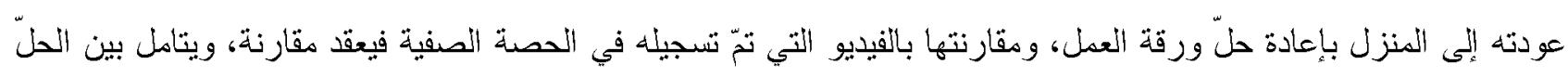
الذبي تمّ في الغزفة الصفية، وبين الحل الأي قام به في المنزل، مدا جعله يتأمل في كل جزئية من جزئيات حلّ ورقة العمل. ويُضداف إلى ذلك أنَّ المنصدات التعليمية تضمنت الاختبار الإكتروني لكل درس، حيث يقوم جميع الطلاب بحلّه، وتم فيه إعطاء تغذية راجعة فورية عن للإجابات، سواء أكانت صحيحة أم غير صحيحة؛ مما أتاح للطالب فرصة المقارنة و التأمل بين حلّه للاختبار، و الحلّ على المنصدة، ليصل الطالب بهذا التأمل لاكتشاف أخطائه في أثناء الحصة، ومر اجعتها فيما بعد، وعملية المر اجعة هذه هي عملية تأملية لما قدمه، وسيقدمه بصورة أخرى، ومن ثم مناقثة ذلك بالتعبير عن الأفكار، و التأملات التي خلص إليها. وقد أتاحت المنصات التعلبمة الفرصة للطلاب للمشاركة الفاعلة في النقاشات التي يتم طرحها أثناء الحصة بطريقة التملّم المقلوب، و الذى يستند في أُساس تكوينه إلى مفاهيم مثل التعلّم النشط، وفاعلية الطلاب، ومشاركتهم في عمليات العلم، وادر اكهم اللمفاهيم العلمية، فقيه تمّ تحويل الصف إلى ورشدة تدريبية منحت الطلاب فرصدة مذاقثثة واستقصداء ما يريدون بحثه حول المحتوى التعليمي، وتوظيف المعرفة و التو اصل مع بعضهم البعض أثناء أُدائهم نلأنثطة الصفية، وذلك بقيام الطلاب بمثاهدة الحصص المسجلة على المنصة، ومر اجعتها فيما بعد لمن أر اد من الطلاب، والتأمل فيما قدموه في الحصة، وفيما سيقدموند بصورة أخرى، وهذه النقاشات التفاعلة التي أتاحتها المنصات التعليمية أثثاء التعلّم؛ حولت الطلاب إلىى عناصر فاعلة ومشاركة ومناقثة ومتأملة، مما أبعد الرتابة عن الحصدة الصفية، وشجعهم على التعبير عن أفكارهم، وتأملاتهم في الأنشطة المختلفة التي 
قُدّمت لهم في المنصات التُعليمية في كل درس من الدروس؛ مما أضفى المتعة على عملية التعلّم، وز اد من مستوى تفكيرهم التأملي.

كما أنَّ المنصات التعليمية التي بُنيت بثكل راعى تصديم وحدة المجسمات، وتقسيهها إلى موضوعات جزئية صغيرة ساعدت الطلاب على فهم أجزائها، وتذكرها بشكل أعمق، و التفكير فيها، وتأملها مرات متعددة بشكل ساعدهم على زيادة مستوى التفكير في تلك المفاهيم حسب قدرات الطالب، وأسلوبه، وأنماط تعلّمه؛ مدا أدى إلىى اكتثاف الأنماط الذهنية، وتكوين المعاني، وساعد الدماغ على حفظ هذه المفاهيم، ومعالجتها في الذاكرة طويلة الأمد، وهذا ما لا توفره الطريقة الاعتيادية في التدريس. وقد يعزو الباحثان تفوق المنصدات التعليمية إلى أنهّا راعت حواس الطالب المختلفة، ولم تعتد على حاسة واحدة وساعد ذلك الطلاب على اكتساب المفاهيم الخاصة بالمجسات، وجعل تلك المفاهيم لها معنى أكثر من الحفظ الأصم لها، ونتيجة لوجود هذا التعلّم ذب المعنى لدى الطلاب زاد لديهم مستوى التقكير، و التأمل، و التحليل لهذه الدفاهيم. وخاصدة أنَّ المنصات التعليمية

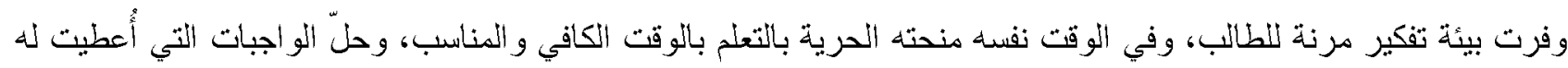
أثناء الحصدة أو في البيت، فربما ساعدث هذه البيئة دماغ الطالب على معالجة هذه المفاهيم بشكل كامل أو جزئي، وربط التعلّم الجديد فيما تعلمه سابقا؛ مما أتاح له تفعيل أستخدام مهارة التأمل و الملاحظة، والكثف عن بعض المغالطات، و المفاهيم البديلة، وتصحيحها، واسنتتاج هفاهيم جديدة، والتوصل إلى أسباب مقنعة، وحل المسائل بشكل سليم، و هذه المهارات مهارات أساسية للتفكير التأملي وفرها استخدام المنصات التعليمية للطالب. وهنالك سبب آخر في تفوق المنصدات التعليمية، قد يعود إلىى أنَّ للمعلم دوراً كبيرًا في تعليم الطلاب مهارات التفكير التأملي؛ لكونه أخذ دور المُوجه و المُبسر، والقائد للعملية التعليمية، وحثه الطلاب على التأمل، والتعامل مع المنصات التعليمية في كل درس من دروس المجسات، وتقديم الإزشادات التي سهت على الطلاب التعامل مع تلاك المنصات؛ مها أدى إلى تتمية مهار ات التفكير التأملي لديهر. وقد تكون هذه الأسباب كلها مجتمعد أدت إلى تقوية مهارات التفكير التأملي لدى الطلاب، وهذا ما ميز المجموعة التي استخدمت المنصات التتليمية على المجموعة الضدبطة التي استخدمت الطريقة الاعتيادية و اتفقت هذه النتيجة مع نتائج دراسة كل من الحدرب (2018)، والتي أشارت نتائجها إلى فاعلية المنصات التحليمبة في المتغيرات التابعة المتعددة كمهار ات التفكير، و الأداء المهاري. وقد يعزى وجود أثر دال إحصائياً للرحلات المعرفية في تتمية مهارات التفكير التأملي لدى الطلاب مقارنة بانطريقة الاعتيادية إلى عدة مز ايا منعددة موجودة في طريقة الرحلات المعرفية. فقد يكون لهذا النهج الجديد في هذه الطريقة التي لم يتعود عليها الطلاب من السابق خاصدة، وأنها تقوم على استخدام الإنترنت، والتقينات الحديثة، و التي تتو افق وميولهم ورغباتهم

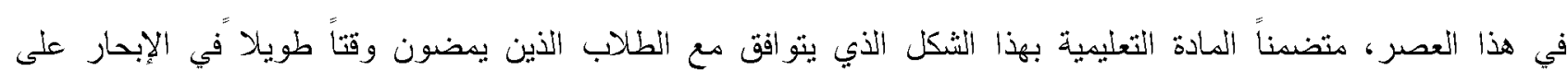
الإنترنت، وجعل مادة وحدة المجسمات في مركز اهتمادهر. كما أنَّ هذه الطريقة مكنت الطلاب من التعامل مع المادة التعليمية، و التوصل إلى معارفها، ومفاهيمها بأنفسهم، وذلك بتنفيذهم المهمات المطلوبة منهم مما جعل المادة الدراسية مدتعة لديهم، مما عزز ذلك تقتهم بأنفسه، و البحث عن المفاهيم، 
و التعمق فيها، وجعلها ذات معنى لديهم. فضلاً عن فيام الطلاب بجمع المعلومات والبيانات والأدلة، وتعرف وجهات النظر حولها من النقاثنات التي تجري بين الطلاب؛ مدا ساعدهم على مدارسة مهار ات التفكير العلياء ومنها مهار ات التفكير التأملي. إنَّ هذه الطريقة تُر اعي دور الطالب في عملية التعلّم، بحيث جعلته فاعلاً أثثاء النقاثُات حون المفاهيم المتعلقة بالمادة ليقوم كل طالب بعرض وتقديم ما أعده من مهمات، وأدائها أمام زملائه، إذ أسهم ذلك في تتمية القدرة على التفكير، و التحقق من دقة المعلومات، و التأمل فيها. وقد يعود السبب أيضاً إلىى أنَّ التقويم الذبي مارسد الطلاب بعدة وسائل كقوائم الرصد، و الثُطب، وغيرها في تقييم أدائهم؛ كان له أثز كبير في توليد القناعة لكل فرد بإمكانياته وقدر اته ومهار اته، وجعل الطلاب يبذلون مزيداً من الجهد و التفكير و الثأمل. و اتفقت النتائج الحالية في هذا الدجال مع نتائج دراسة الفار (2011)، التي أظهرت تفوق الرحلات المعرفية في مستوى التفكير التأملي، و اتفقت مع نتائج دراسة صبري و الجني (2013)، والتي أظهرت فاعلية لاستر اتيجية الرحلات المعرفية في تتمية مهار ات عمليات العلم، و اتفقت أخيراً مع نتائج دراسة الثيخ (2016)، و التي بينت نتائجها أنَّ هناكَ أثراً دالاً إحصائياً للرحلات المعرفية في تتمية مهار ات التقكير التأملي. بينما خالفت هذه النتيجة نتائج دراسة عبد المجيد (2014) التي كثفت أنَّ استخدام استر اتيجية الويب كويست لم تُساهم في تحسين مستوى مهار اتي الوصول إلى أستتاجات، و إعطاء تفسير ات مقنعة. وقد بعزى وجود أثر دال إحصائياً للمنصات التعليمية في تتمية مهار ات التفكير التأملي لدى الطلاب مقارنة بالرحلات المعرفية على الر غم من أنَّ الطريقتين استخدمتا التكنولوجيا الحديثة، إلا أنَّ وجود بعض المز ايا التفاعلية في المنصات التعليمة بدرجة أكثر مرونة من الرحلات المعرفية، علماً بأنَّ المنصات التعليمية كان فيها فيديوهات مباشرة، وأسئلة إلكترونية مباشرة حول المادة التعليمية يقوم معلم متخصص بشرحها، وهذا المعلم من الكادر التدريس الموجود في المدرسة الذي له دراية عن مستوى الطلاب، والفروق الفردية بينه، وربما تكون هذه الوسائل التي استخدمت المنصدات التعليمية قد صيغت بدقة تتناسب مع مستوى الطلاب، وأدت إلىى استخدامهم التفكير التأملي بشكل أفضل من الذين استخدموا الرحلات المعرفية، وخاصدة أنَّ الإبحار حول الثبكة العنكبوتية له بعض السلبيات، كالنتشت و الضباع في المو اقع الإليكترونية.

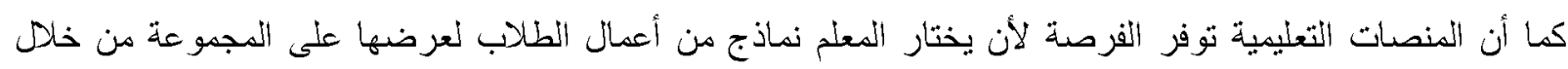
منتدى النقاش، و إتاحة الفرصدة للطلاب بتقديم تعليقات ذات معنى على واجبات زملاثه، مما كان ذه الأثر الؤاضح في تتمية التفكير التأملي لدبهم.

$$
\text { في ضوء النتائج التي توصلت إليها الدراسة فإنها توصي بالآتي: }
$$

-ضرورة استخدام معلمي الزرياضيات للمنصات التعليمية، والرحلات المعرفية كأحد طرائق تدريس الطلاب لمبحث الرياضيات.

ينصح قيام أقسام الإثر اف و التدريب في المؤسسات التعليمية بتدريب معلمي الرياضات على كيفية إعداد البرامج التعليمية القائمة على المنصات التعليمية و الترحلات المعرفية، وحثهم على استخدامها في تدريسهر. -بناء تقافة عن المعلمين و الطلبة والأهالي بإعتماد الوسائل التكنولوجية الحديثة لما لها من أثر إيجابي في تتمية التفكير. 


\section{المصادر والمراجع}

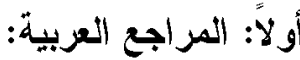

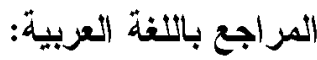

الأستاذ، محمود حسن (2011). مستوى القدرة على التفكير التأملي لدى معلمي العلوم في المرحلة الأساسية بغزة. مجلة جامعة

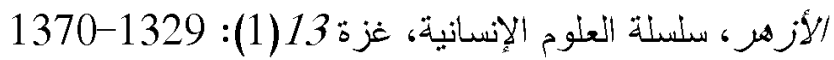

أبو جبلة، اسماعيل (2017). أثر استخدام الرحلات المعرفية في تتمية التفكير البصري في مقرر الرياضيات لدى طالبات

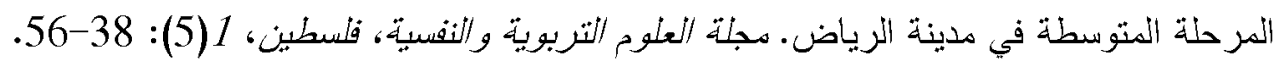

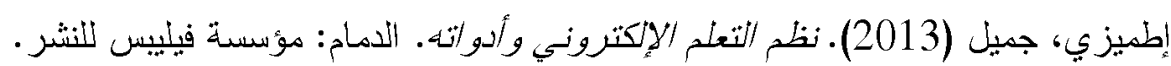
الجمل، توكل (2016). فاعلية الرحلات المعرفية عبر الويب في الاستيعاب الكفاهيمي وتتمية مهار ات التنفير التأملي من خلال

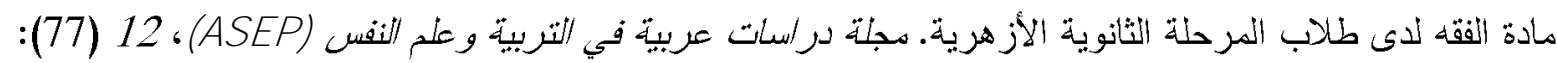

الجهني، ليلى (2016). تقصي نو ايا طالبات الدراسات العليا السلوكية في استخدام منصة ادمودو Edmodo التعليمية مستقبلاً

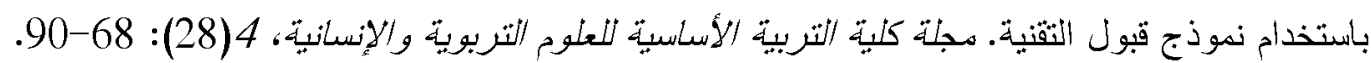

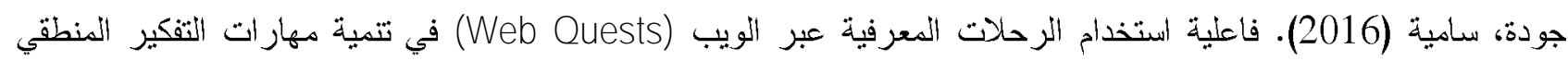

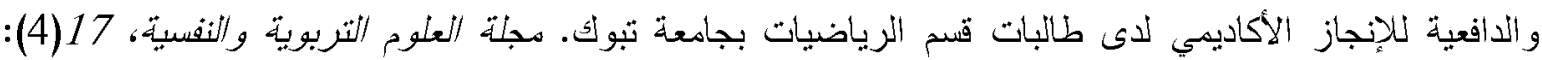
$.228-187$

الحدرب، كوثر (2018). فاعلية توظيف الدنصات النعليمية في التفكير العلدي، والدهارات الحباتية لدى طلبة كلية العلوم

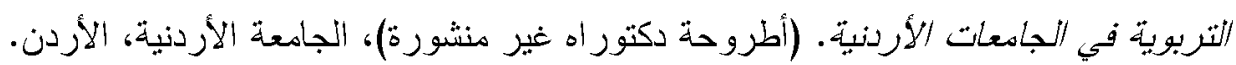

Al Hudrub, K.(2018). The Effectiveness of the Google Classroom in Developing of the Scientific Thinking and Life Skills for Students of the Faculty of Educational Science at the University of Jordan (in Arabic). Unpublished dissertation, Jordan University, Jordan.

الحربي، سلمى (2016). معوقات توظيف الزحلات المعرفية عبر ويب كويست (Web Quests) في تدريس اللغة الإنجليزية

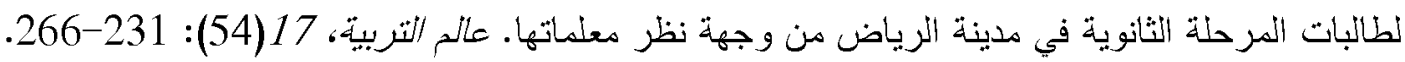

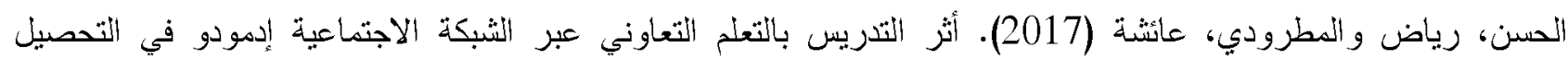

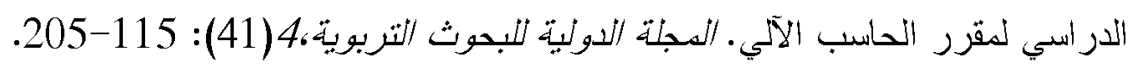

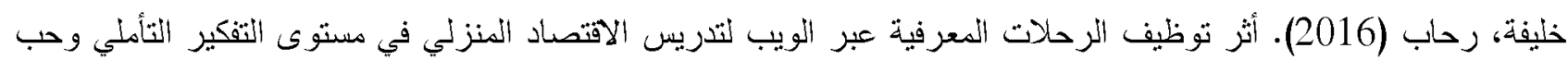

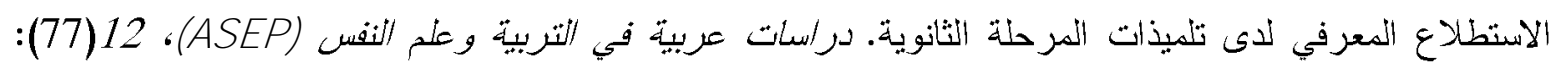

دحلان، عثمان (2012). فاعلية برنامج معزز بنظام 141- لإكساب طلاب النعليم الأساسي بجامعة الأزهر مهارات التخطبط اليومي للاروس واتجاهاتهم نحوه. (رسالة ماجستير غير منثورة)، جامعة الأزهر ، فلسطين.

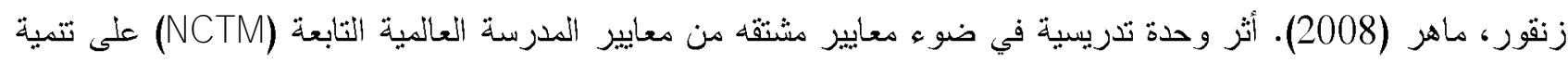

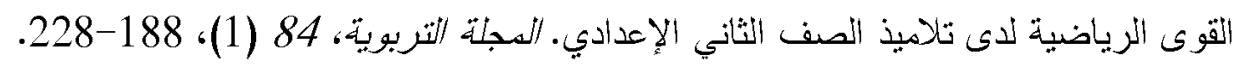

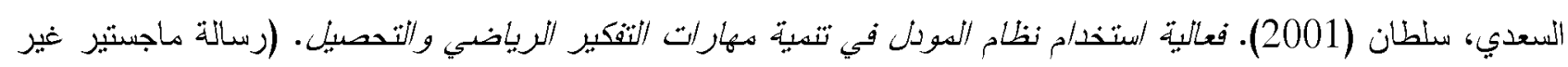

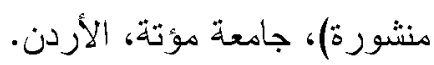


سمارة، نسرين (2013). أثر /ستخدام /ستر/تيجية الويب كويست (الرحات المعرفية) في التحصيل المباشر والمؤجل لدى الدي

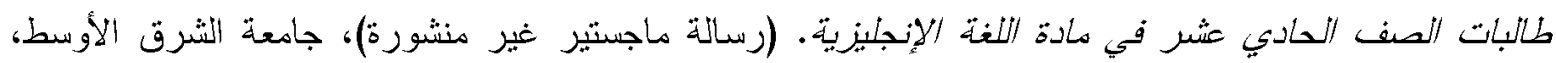
الأردن. النان.

الثيخ، أسماء (2016). أثر الرحلات المعرفية عبر الويب (Web Quests) في تتمية مهارات التفكير التأملي والاتجاه نحو التاني

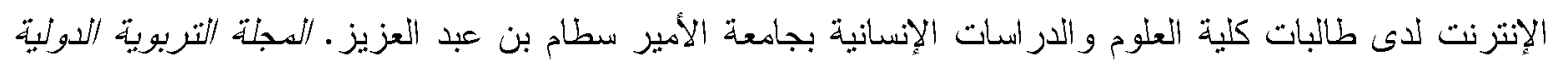

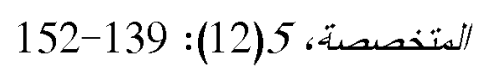

صالح، محمد (2014). فاعلية الرحلات المعرفية عبر الويب لتنديس الكيمياء في تنتية التفكير التأملي والتحصيل الدراسي

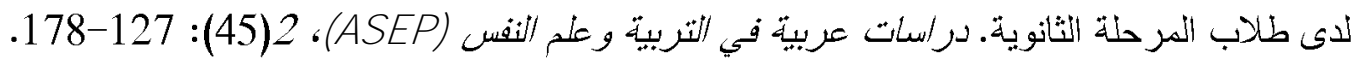

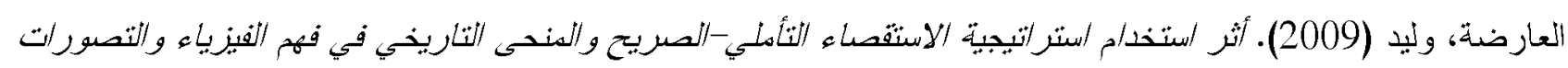

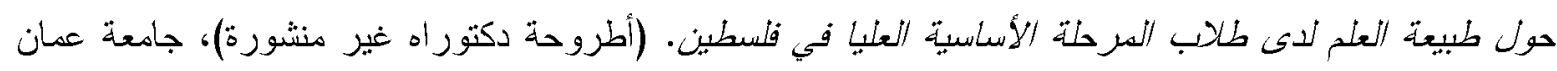
العربية، الأردن.

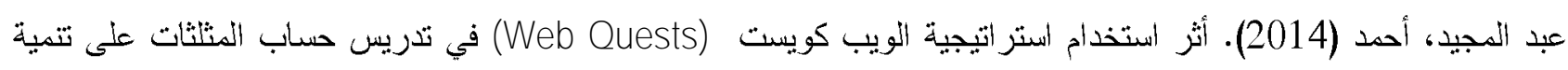

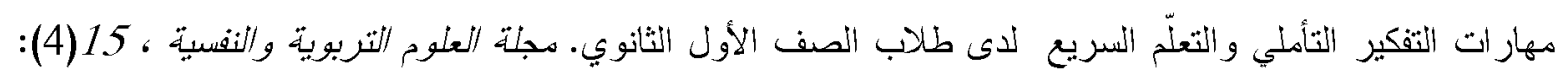
$.88-48$

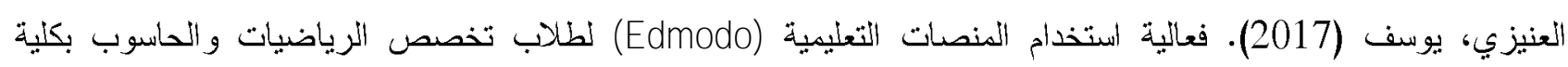

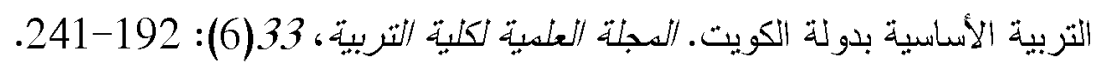

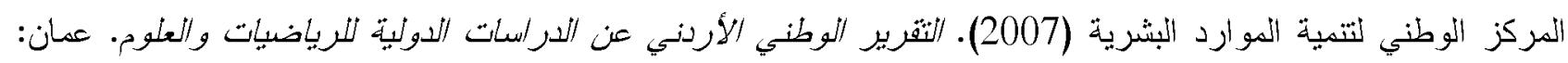
الأزردن.

المركز الوطني لتنمية الموارد البشرية (2011). الثقرير الوطني الأردني عن الدراسات الدولية للرياضيات والعلوم، عمان: الأزردن.

المركز الوطني لتنمية الموارد البشرية (2015). الثنقرير الوطني الأردني عن الدر/سات الدولية للرياضيات والعلوم، عمان: الأزدن.

مصطفى، عادل (2017). فاعلية استراتيجية الويب كويست في تتمية التفكير الناقد في الرياضيات، والاتجاه نحو التعلم القائم

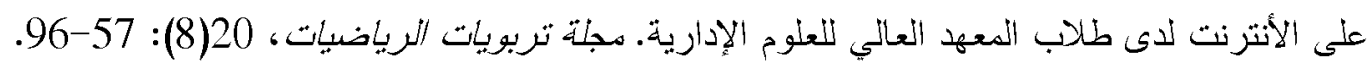

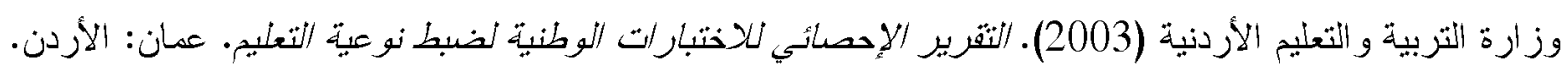

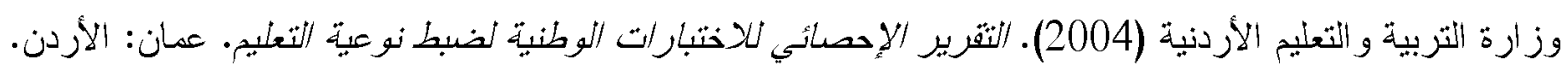

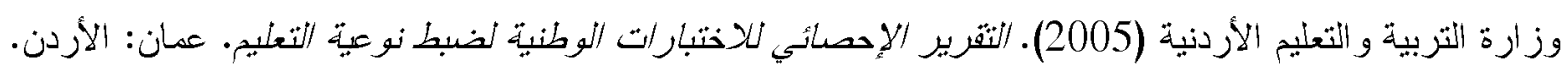

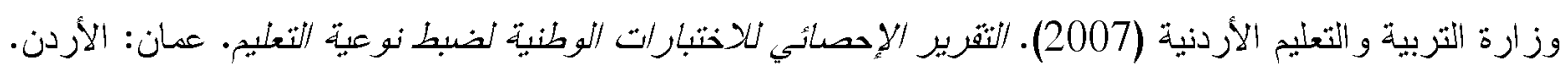

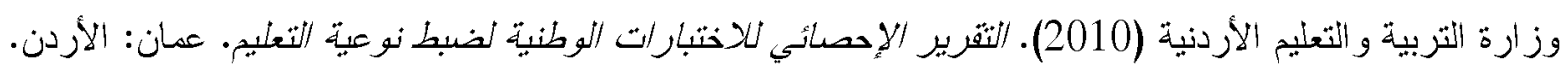

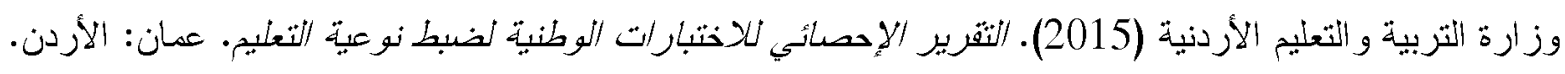
وز ارة التربية و التعليم الأردنية (2017). الثنقرير الإحصائي للاختبارات الوطنية لضبط نوعية التعليم. عمان: الأردن. 
Abdelmagid. Ahmad. (2014). The Effect of Using the Web Quest Strategy in Teaching Trigonometry on the Development of Reflective Thinking Skills and Rapid Learning for the First Grade Secondary Students (in Arabic). Journal of Educational and Psychological Sciences 15(4), 48- 88.

Abu Jablah, Esmail. (2017). The effects of using the Web Quest on developing the visual thinking of the female students in the second grade of the intermediate level in Riyadh (in Arabic). J ournal of Educational and Psychological Sciences 1(5), 38- 56.

Al Ardah, Walid. (2009). The Effect of Using the Explicit Reflective Inquiry Strategy and the Historical Approach on Understanding Physics and the Conceptions about the Nature of Science by the Higher Basic Stage Students in Palestine (in Arabic). Unpublished Thesis, Amman Arab University, J ordan.

Al Enizi, Yousef. (2017). The effectiveness of using educational platforms (Edmodo) for students majoring in mathematics and computer at the College of Basic Education in the State of Kuwait (in Arabic). Journal of Faculty of Education 33(6), 192- 241.

Al Harbi, Salma. (2016). Obstacles to Employing Cognitive J ourneys through Web Quests in Teaching English to secondary school students in Riyadh from the point of view of their teachers (in Arabic). Alam al- Tarbiyah 17(54), 231- 266.

Al Hsan, Riyad. \& Al Matrodi, A. (2017). The effect of teaching using cooperative learning through educational social network (Edmodo) on the academic achievement in a computer course (in Arabic). International J ournal for Research in Education 4(41), 115- 205.

Al Hudrub, Kawthar.(2018). The Effectiveness of the Google Classroom in Developing of the Scientific Thinking and Life Skills for Students of the Faculty of Educational Science at the University of J ordan (in Arabic). Unpublished dissertation, J ordan University, J ordan.

Al J amal, Tawakol. (2016). The Effectiveness of the Web-Based Cognitive Trips for Absorbing and Developing the Conceptual Contemplative Thinking Skills through Studying J urisprudence for the Al-Azhar Secondary Stage Students (in Arabic). Journal of Arab Studies in Education and Psychology 12(77), 197- 245.

Al Saidi, Sultan. (2001). The effectiveness of using Moodle system in developing mathematical thinking skills and academic achievement among grade seven students (in Arabic). Unpublished Thesis, Mutah University- J ordan.

Al Sheqe, Asma. (2016). The Impact of Using Strategies' (Web Quest) in the Development of Reflective Thinking Skills and the Trend towards Online Students at the Faculty of 


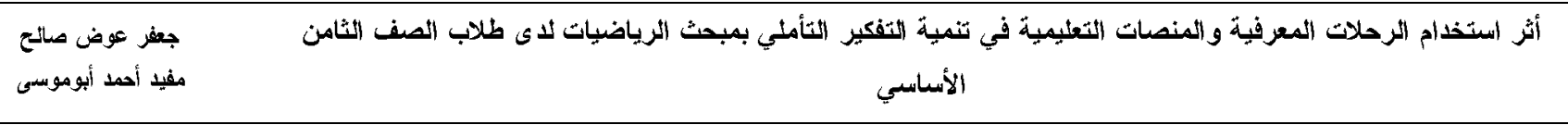

Science and Studies,Prince Sattam Bin Abdulaziz University Skills (in Arabic). The International Interdisciplinary J ournal of Education 5(12), 139- 152.

Aljohani, Lylah. (2016). Investigating the behavioral intentions of graduate female students to use Edmodo instructional platform in the future by using the technology acceptance model (in Arabic). Basic Education College Magazine For Educational and Humanities Sciences 4(28), 68- 90.

Al- Ostath, Mahmoud (2001). The level of Reflective Thinking among Science Teachers in Primary Grades in Gaza (in Arabic). J ournal of Al-Azhar University: Humanities 13(1), 1329- 1370.

Al-Shamisi, A. (2016). The Effect of Web quests on Grade 11 Reading Comprehension and Student Perceptions of Webquests. American International J ournal of Contemporary Research. 6(1), 132-143.

Auditor, E., \& Roleda, L. (2014). The Web quest: It is Impact on Students' Critical Thinking, Performance, and And Perceptions in Physics. International Journal of Research Studies in Educational Technology, 3(1): 2243- 7738.

Calgin, Z. \& koc, M.(2017). The effect of Web Quest - Supported Mathematics Instruction on Sixth Grade Students, Critical Thinking Skills. Necatibey Faculty of Education J ournal of Sciene and Mathematics Education, 11(1): 1- 20.

Chatel, R. \& Nodell, J. (2002). Web quests: Teachers and Students as Global Literacy Explorers.

Retrieved Dec 16, 2018, From: Http:// www.Eric.Ed.Gov.

Costa, C., Alvelos, H., \& Teixeira, L. (2012). The Use of Moodle E- Learning Platform: A Study in a Portuguese University. Procedia Technology, 5, 334- 343.

Dahlan, Othman. (2012). The effectiveness of a program enhanced by Moodle system on primary education male students acquisition of planning skills and their attitudes towards it at AlAzhar University (in Arabic). Unpublished Thesis, AL- Azhar University, Gaza.

Dodge, B. (2001). FOCUS: Five Rules for Writing a Great Web quest. Learning and Leading With Technology, 28(8), 6- 9.

El-Bahsh, R., Daoud, M. (2016). Evaluating the use of MOODLE to achieve effective and interactive learning: $A$ case study at the German Jordanian University. In Proceedings of the 35th Annual IEEE International Conference on Computer Communications, 1- 5.

Etemezi, J ameel. (2013). Systems of e- Learning and its Tools (in Arabic). Damam, Philips Publication.

Fiedler, R. \& Allen, K. (2002). Web Quests: A Critical Examination In Light Of Selected Learning Theories. Retrieved May 28, 2018, from: http://www. beckyfiedler.com/wq/fiedler.pd 


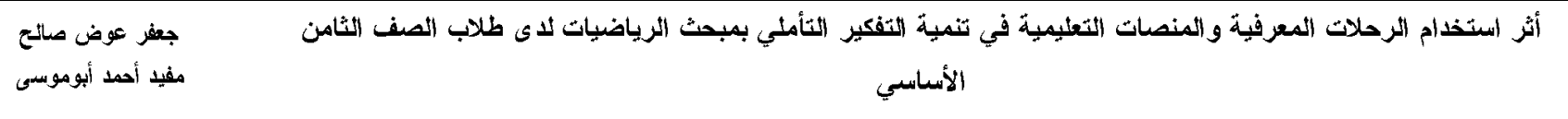

Hassanien, A. (2006). Using Web quest to Support Learning with Technology in Higher Education. Journal of Hospitality, Leisure, Sport and Tourism Education, 5(1): 4149.

Judah, Samyah. (2016). The Effectiveness of using Web Quests in Developing some Logical Thinking Skills and Academic Achievement Motivation among Mathematics Department students at Tabuk university (in Arabic). Journal of Educational and Psychological Sciences 17(4), 187- 228.

Khlefa, Rehab. (2016). The impact of employing cognitive trips across the web (WebQuests) to teach home economics in the development of reflective thinking and curiosity cognitive for secondary school pupils (in Arabic). Journal of Arab studies in education and Psychology 12(77), 141- 193.

Lamb, A. (2004): Key Words In Instruction: Web Quests. School Library Media Activities Monthly, 21(2): 38- 40.

Li, H .\& yang, Y. (2007). The Effectiveness of Web Quest on Elementary School Student's Higher-order Thinking, Learning Motivation, and English learning Achievement. In Proceedings of World Conference on Educational Multimedia, Hypermedia \& Telecommucation, Chesapeake

Lyons, N. (2010) . Handbook Of Reflection and Reflective Inquiry: Mapping a Way of Knowing for

Professional Reflective Inquiry. International Journal of Business Management and Economic, Research, 7(5): 754- 762.

Malley, L. (2020, 3 24). Trends in International Mathematics and Science Study (TIMSS).

Retrieved from Trends in International Mathematics and Science Study (TIMSS): https://nces.ed. gov/timss/.

Ministry of Education J ordan (2003). Statistical report of the national tests to control the quality of education (in Arabic). Amman, Jordan.

Ministry of Education J ordan (2004). Statistical report of the national tests to control the quality of education (in Arabic). Amman, J ordan.

Ministry of Education J ordan (2005). Statistical report of the national tests to control the quality of education (in Arabic). Amman, J ordan.

Ministry of Education J ordan (2007). Statistical report of the national tests to control the quality of education (in Arabic). Amman, Jordan.

Ministry of Education J ordan (2010). Statistical report of the national tests to control the quality of education (in Arabic). Amman, J ordan. 


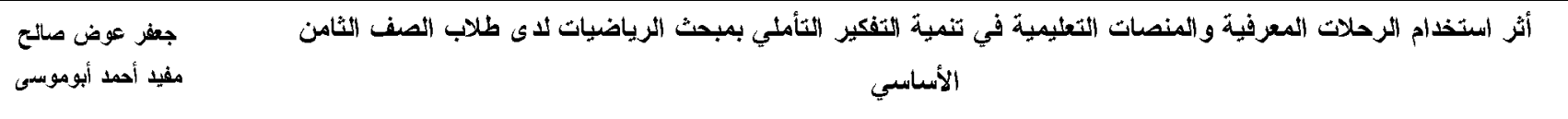

Ministry of Education J ordan (2015). Statistical report of the national tests to control the quality of education (in Arabic). Amman, Jordan.

Ministry of Education J ordan (2017). Statistical report of the national tests to control the quality of education (in Arabic). Amman, Jordan.

Mustafa, Adel (2017). The Effectiveness of Web Quest Strategy on Developing Critical Thinking in Mathematics and Boosting Internet-Based Learning among Students of Cairo Higher Institute for Administrative Sciences (in Arabic). Journal of Mathematics Education 20(8), 57- 96.

National Center for Human Resource Development (2007). Jordanian National Report on International Studies in Mathematics and Science (in Arabic). Amman, J ordan.

National Center for Human Resource Development (2011). Jordanian National Report on International Studies in Mathematics and Science (in Arabic). Amman, Jordan.

National Center for Human Resource Development (2015). Jordanian National Report on International Studies in Mathematics and Science (in Arabic). Amman, Jordan.

Saleh, Mohamad. (2014). The Effectiveness of Web Quest in Chemistry Teaching to Development of Reflective Thinking and Achievement among Secondary Stage Students (in Arabic). J ournal of Arab Studies in Education and Psychology 2(45), 127- 178.

Samara, Nesrin. (2013). The Effect of Using the Web Quest Strategy on Immediate and Delayed Achievement in English Language Course of the First Secondary Female Students (in Arabic). Unpublished Thesis, Middle East University-J ordan.

Skylar, A. A., Higgins, K., \& Boone, R. (2007). Strategies for Adapting Web quests for Students with Learning Disabilities. Intervention in School and Clinic, 43(1): 20- 28.

Wallace, A. (2013, September). Social Learning Platforms and the Flipped Classroom. In 2013 Second International Conference on E-Learning and E-Technologies in Education (ICEEE) (Pp. 198-200). IEEE.

Zanqoor, Maher. (2008). The effect of a teaching unit in the light of criteria derived from the International School Standards (NCTM) on the development of mathematical strengths for second year preparatory students (in Arabic). Educational J ournal 84(1), 188- 228. 